\title{
Article
}

\section{Zinc Enrichment in Two Contrasting Genotypes of Triticum aestivum L. Grains: Interactions between Edaphic Conditions and Foliar Fertilizers}

\author{
Inês Carmo Luís ${ }^{1,2}, *\left(\mathbb{D}\right.$, Fernando C. Lidon ${ }^{1,2}$, Cláudia Campos Pessoa ${ }^{1,2} \mathbb{D}$, Ana Coelho Marques ${ }^{1,2}$, \\ Ana Rita F. Coelho 1,2(D), Manuela Simões 1,2 ${ }^{10}$, Manuel Patanita 2,3, José Dôres ${ }^{3}$, José C. Ramalho ${ }^{2,4}$, \\ Maria Manuela Silva 2,5 (D), Ana Sofia Almeida 2,6 ${ }^{(D}$, Isabel P. Pais ${ }^{2,7}$, Maria Fernanda Pessoa 1,2, \\ Fernando Henrique Reboredo ${ }^{1,2}$, , Paulo Legoinha ${ }^{1,2}$, Mauro Guerra ${ }^{8}$ (D), Roberta G. Leitão ${ }^{8}$ \\ and Paula Scotti Campos 2,7 (D)
}

\section{check for} updates

Citation: Luís, I.C.; Lidon, F.C.; Pessoa, C.C.; Marques, A.C.; Coelho, A.R.F.; Simões, M.; Patanita, M.; Dôres, J.; Ramalho, J.C.; Silva, M.M.; et al. Zinc Enrichment in Two Contrasting Genotypes of Triticum aestivum L. Grains: Interactions between Edaphic Conditions and Foliar Fertilizers. Plants 2021, 10, 204. https://doi.org/10.3390/plants 10020204

Academic Editor: Ivana Puglisi

Received: 27 December 2020

Accepted: 18 January 2021

Published: 21 January 2021

Publisher's Note: MDPI stays neutral with regard to jurisdictional claims in published maps and institutional affiliations.

Copyright: (c) 2021 by the authors. Licensee MDPI, Basel, Switzerland. This article is an open access article distributed under the terms and conditions of the Creative Commons Attribution (CC BY) license (https:// creativecommons.org/licenses/by/ $4.0 /)$.
1 Earth Sciences Department, Faculdade de Ciências e Tecnologia, Campus da Caparica, Universidade Nova de Lisboa, 2829-516 Caparica, Portugal; fj@@ft.unl.pt (F.C.L.); c.pessoa@campus.fct.unl.pt (C.C.P.); amc.marques@campus.fct.unl.pt (A.C.M.); arf.coelho@campus.fct.unl.pt (A.R.F.C.); mmsr@fct.unl.pt (M.S.); mfgp@fct.unl.pt (M.F.P.); fhr@fct.unl.pt (F.H.R.); pal@fct.unl.pt (P.L.)

2 GeoBioTec Research Center, Faculdade de Ciências e Tecnologia, Campus da Caparica, Universidade Nova de Lisboa, 2829-516 Caparica, Portugal; mpatanita@ipbeja.pt (M.P.); cochichor@mail.telepac.pt (J.C.R.); abreusilva.manuela@gmail.com (M.M.S.); sofia.almeida@iniav.pt (A.S.A.); isabel.pais@iniav.pt (I.P.P.); paula.scotti@iniav.pt (P.S.C.)

3 Escola Superior Agrária, Instituto Politécnico de Beja, R. Pedro Soares S/N, 7800-295 Beja, Portugal; jdores@ipbeja.pt

4 PlantStress \& Biodiversity Lab, Centro de Estudos Florestais (CEF), Instituto Superior Agronomia (ISA), Universidade de Lisboa (ULisboa), Quinta do Marquês, Av. República, 2784-505 Oeiras, Portugal

ESEAG-COFAC, Avenida do Campo Grande 376, 1749-024 Lisboa, Portugal

6 Instituto Nacional de Investigação Agrária e Veterinária, I.P. (INIAV), Estrada de Gil Vaz 6, 7351-901 Elvas, Portugal

7 Instituto Nacional de Investigação Agrária e Veterinária, I.P. (INIAV), Avenida da República, Quinta do Marquês, 2780-157 Oeiras, Portugal

8 LIBPhys-UNL, Physics Department, Faculdade de Ciências e Tecnologia, Campus da Caparica, Universidade Nova de Lisboa, 2829-516 Caparica, Portugal; mguerra@fct.unl.pt (M.G.); rg.leitao@fct.unl.pt (R.G.L.)

* Correspondence: idc.rodrigues@campus.fct.unl.pt

Abstract: This study aimed to assess the implications of $\mathrm{Zn}$ enrichment in wheat grains as a function of contrasting genotypes, edaphic conditions and foliar fertilizers. Triticum aestivum L. varieties Roxo and Paiva were grown in four production fields, and sprayed with $\mathrm{ZnSO}_{4}(0,16.20$ and $36.40 \mathrm{~kg} / \mathrm{ha})$ Zn-EDTA (0, 6.30 and $12.60 \mathrm{~kg} / \mathrm{ha})$ and Tecnifol Zinc (0, 3.90 and $7.80 \mathrm{~kg} / \mathrm{ha})$. The heterogeneous edaphic conditions of the wheat fields were chemically characterized, it being found that soil properties determine different $\mathrm{Zn}$ accumulation in the grains of both genotypes. Foliar spraying enhanced to different extents $\mathrm{Zn}$ content in the grains of both genotypes, but the average of enrichment indexes varied among the wheat fields. Zinc mostly accumulated in the embryo and vascular bundle and to a lesser extent in the endosperm. Grain yield and test weight sprayed by $\mathrm{ZnSO}_{4}$ gave the highest values in both genotypes, but the opposite was found for Zn-EDTA. Considering the color parameters, lightness and red-green transitions were found to be a conjunction of genotype characteristics, fertilization types and edaphic conditions prevailing in each field. It is concluded that the index of $\mathrm{Zn}$ enrichment in wheat grains is a docket of edaphic conditions, genotype and type of fertilization.

Keywords: agronomic biofortification; bread wheat; grain yield; zinc foliar application; zinc grain content

\section{Introduction}

By 2050, several estimates suggest that the world population will reach about 9.7 billion people, emphasizing huge disparities between developed and developing countries $[1,2]$, 
which creates an urgent need for an increasing production of staple foods. Besides, the concentration and bioavailability of micronutrients required for the human diet have decreased in staple foods [3]. In fact, nowadays about 3 billion people suffer from malnutrition, approximately 2 billion have micronutrients deficiencies, 1.9 billion are obese or overweight and 821 million are undernourished [4,5]. Malnutrition also affects about one in three people, contributing to $45 \%$ of child deaths and major risks of contracting infectious diseases, wasting and/or stunting, reduced early child cognitive development and developing chronic diseases that are not contagious [5,6]. Micronutrient deficiencies in developing countries further diminish work productivity and increase healthcare costs, leading these countries to great economic losses $[3,7,8]$. Additionally, although the recommended dietary allowance (RDA) of $\mathrm{Zn}$ for adults is, approximately, $8 \mathrm{mg} /$ day for women and $11 \mathrm{mg} /$ day for men [9], poor $\mathrm{Zn}$ intake, high loss and low solubility determines Zn deficiency [10], leading to a weakening of the immune system, loss of brain function and changes in physical growth $[4,10]$. Additionally, there are some other diseases and health conditions associated with Zn deficiency such as cancer, risk of infections, infertility, problems regarding learning skills and mental lethargy. Nevertheless, Zn excess in a diet might also cause some diseases, namely, altered lymphocyte function, epigastria pain and nausea [11].

A poor diet in micronutrients can lead to physiological lacks, especially if consumers ingest plant-derived foods. This applies not only to the consumption of edible plant parts with a low concentration of micronutrients, but also to plant growth in soils with poor nutrient availability that can culminate in nutrient deficiencies in the world population $[3,6,12]$. In this context, in 2020, the world production of wheat will probably reach 762.6 million tons [13] but will only keep an average consumption of $67.5 \mathrm{~kg}$ per person a year $[12,14]$. Therefore, human dependence upon cereals with a poor $\mathrm{Zn}$ status deepens the gap between the available amount and the amount required for good health, which is $40-50 \mathrm{mg} / \mathrm{kg}$ [15]. Indeed, although in plants the normal $\mathrm{Zn}$ concentration might range between 25 and $150 \mathrm{mg} / \mathrm{kg}$, this nutrient content is lower in bread wheat grains (varying between $20-35 \mathrm{mg} / \mathrm{kg}$, with an average value ranging between $28-30 \mathrm{mg} / \mathrm{kg}$ ) [7]. Zinc has a large number of functions such as playing an important role in plant growth, namely as a co-factor in the auxin metabolism, enzymatic activation and synthesis of chlorophyll and nucleotides [7,16]. Likewise, $\mathrm{Zn}$ is also important in the expression and regulation of genes [17] and $\mathrm{Zn}$ transport from roots to the xylem can be apoplastic, but the symplastic circulation prevails [18]. In the xylem, $\mathrm{Zn}$ flows in its ionic form $\left(\mathrm{Zn}^{2+}\right)$ or complexed with histidine and nicotinamide, occurring complexed with organic acids in the chloroplast [19-21]. The $\mathrm{Zn}^{2+}$ is further transported to the leaves and is moved in the phloem by ZIPs and YSL proteins, and it can be mediated by ZIPs (ZIP1, ZIP3 and ZIP4), or by $\mathrm{Ca}^{2+}$ channels in plasmatic membranes [11,22]. Bread wheat, as a staple food, can be considered a good target for $\mathrm{Zn}$ biofortification (i.e., for enrichment of the content or the nutrient bioavailability in the edible parts of staple crops during plant growth) $[7,23-26]$. From an agronomic perspective, the crucial time to apply $\mathrm{Zn}$ to wheat crops is during the grain filling [7], due to the intense flow of nutrients from vegetative organs to the grains, such as the root capture of $\mathrm{Zn}$ from soils, its translocation to the shoots and further remobilization of stored nutrients in leaves [21]. Besides, the application of adequate NPK fertilizers can further optimize the effects of foliar and soil applications of $\mathrm{Zn}$ [7]. Yet, more than $30 \%$ of the world soils present $\mathrm{Zn}$ deficiencies [11] and its concentration, generally, ranges between 6-28 mg/kg [8]. Besides, different levels of Zn deficiencies in soils (particularly calcareous soils) trigger distinct susceptibility in crops (namely its strong deficiency) and its application in soils is less efficient than foliar spraying when it comes to grain accumulation [6,11]. Nevertheless, soil fertilization with Zn promotes a high grain yield [11,27], but a combined application of soil and foliar spraying further results in an increased grain yield and $\mathrm{Zn}$ accumulation [28]. In this context, through foliar spraying, the uptake of inorganic nutrients, namely $\mathrm{Zn}$, requires this nutrient movement/absorption across the cuticle (through a dissolution-diffusion process) and/or through the stomatal 
cavity $[29,30])$. Yet, the foliar uptake kinetics are influenced by the characteristics of the leaf surface, including the thickness of the wax layer and the distribution of stomata and trichomes [31-33]. Thereafter, the overall efficacy of Zn movement is linked to its subsequent loading into the foliar vascular systems and translocation via the phloem of primary veins into the other plant tissues [30,34-36]. Zn fertilization, through soil or foliar application, therefore is an effective method for improving this nutrient concentration in the grain [15] Following this assumption, this study aimed to develop an itinerary for $\mathrm{Zn}$ enrichment of Triticum aestivum L. grains, using as test systems Roxo and Paiva Portuguese varieties sprayed with $\mathrm{ZnSO}_{4}$, Zn-EDTA and Tecnifol Zinc (a highly soluble $\mathrm{Zn}$ mixture having Zinc sulphate mono, hexa and heptahydrate). As heterogeneous properties prevail in the soils, both wheat genotypes were $\mathrm{Zn}$ biofortified in four experimental fields, with $\mathrm{Zn}$ accumulation and tissue localization, the yield, test weight, thousand kernel weight, ashes and colorimetric properties being assessed.

\section{Results}

\subsection{Soil Analysis}

The experimental fields 1 and 2 showed (Table 1) have a higher electrochemical conductivity than fields 3 and 4 (in $\mu \mathrm{S} / \mathrm{cm}, 507.44 / 521.78$ and 368.56/328.00, respectively). The $\mathrm{pH}$ showed a similar trend, with fields 3 and 4 revealing the same value $(7.67 / 7.80$ and 6.85 , respectively). The organic matter did not vary significantly in fields 1,2 and 3, but lower values were found in field 4 (to ca. $73.6 \%$, relatively to field 3 ). Moisture displayed the highest value in field 1, being found in significantly lower values in the remaining fields. The contents of $S$ were significantly higher in field 2 but did not vary among the remaining experimental fields. The amount of $\mathrm{K}$ did not change significantly in fields 3 and 4 but remained lower than in fields 1 and 2 (between $10.45 \%$ and $45.11 \%$, relatively to fields 1 and 2). Calcium showed significantly higher values in field 2 (ca. 5.7 fold), whereas field 3 had the lowest value. The levels of Fe did not vary significantly in fields 2 and 4 but remained lower relative to the other fields. The amount of Mn was significantly different among the experimental fields according to the following pattern: field $3>$ field 1 $>$ field $4>$ field 2. Moreover, although $\mathrm{Zn}$ content in the soils of the four wheat fields were $\mathrm{Zn}$-sufficient for keeping an adequate plant status [37], it varied significantly and followed the pattern: field $1>$ field $3>$ field $2>$ field 4 . Contaminants, like As and $\mathrm{Cd}$, were also found in considerable quantities on the experimental fields (except field 4, for As). Contents of $\mathrm{Mg}$ and P remained lower than 1500 and $200 \mathrm{mg} / \mathrm{kg}$, respectively.

Table 1. Analysis of soils $(0-30 \mathrm{~cm})$ of fields $1-4(n=9$ for electrochemical conductivity, $\mathrm{pH}$, organic matter and moisture; $n=27$ for quantification of chemical elements) of Triticum aestivum L., varieties Roxo and Paiva.

\begin{tabular}{|c|c|c|c|c|c|}
\hline Experimental Field & & 1 & 2 & 3 & 4 \\
\hline Electrochemical Conductivity & $\mu \mathrm{S} / \mathrm{cm}$ & $507.44 \pm 30.98 \mathrm{a}$ & $521.78 \pm 36.69 \mathrm{a}$ & $368.56 \pm 19.27 b$ & $328.00 \pm 18.84 b$ \\
\hline $\mathrm{pH}\left(\mathrm{H}_{2} \mathbf{0}\right)$ & - & $7.67 \pm 0.05 \mathrm{a}$ & $7.80 \pm 0.03 \mathrm{a}$ & $6.85 \pm 0.07 b$ & $6.85 \pm 0.07 b$ \\
\hline Organic Matter & & $6.86 \pm 0.06 a$ & $7.07 \pm 0.13 \mathrm{a}$ & $7.23 \pm 0.42 \mathrm{a}$ & $5.32 \pm 0.34 b$ \\
\hline Moisture & & $22.47 \pm 0.14 \mathrm{a}$ & $20.25 \pm 0.65 \mathrm{ab}$ & $19.58 \pm 0.35 b$ & $15.09 \pm 0.90 c$ \\
\hline S & $\%$ & $0.023 \pm 0.001 \mathrm{~b}$ & $0.025 \pm 0.001 \mathrm{a}$ & $0.021 \pm 0.001 \mathrm{~b}$ & $0.020 \pm 0.0004 b$ \\
\hline K & & $0.622 \pm 0.014 \mathrm{a}$ & $0.184 \pm 0.009 b$ & $0.065 \pm 0.001 \mathrm{c}$ & $0.083 \pm 0.0014 \mathrm{c}$ \\
\hline $\mathrm{Ca}$ & & $1.165 \pm 0.060 \mathrm{~b}$ & $6.331 \pm 0.349 \mathrm{a}$ & $1.018 \pm 0.027 \mathrm{~b}$ & $1.103 \pm 0.0284 b$ \\
\hline Mn & & $755.58 \pm 11.41 b$ & $430.61 \pm 21.81 \mathrm{~d}$ & $840.74 \pm 16.23 \mathrm{a}$ & $507.78 \pm 25.69 c$ \\
\hline $\mathrm{Fe}$ & & $38777 \pm 376 \mathrm{~b}$ & $21860 \pm 936 c$ & $46030 \pm 419 a$ & $22440 \pm 746 c$ \\
\hline $\mathrm{Cu}$ & & $46.91 \pm 1.62 \mathrm{~b}$ & $77.73 \pm 7.21 \mathrm{a}$ & $87.04 \pm 1.86 \mathrm{a}$ & $90.82 \pm 3.00 \mathrm{a}$ \\
\hline Zn & & $59.81 \pm 0.77 a$ & $32.52 \pm 2.95 c$ & $40.94 \pm 0.71 b$ & $22.82 \pm 0.61 \mathrm{~d}$ \\
\hline As & $\mathrm{mg} / \mathrm{kg}$ & $10.98 \pm 0.22 \mathrm{a}$ & $5.97 \pm 0.41 \mathrm{~b}$ & $5.61 \pm 0.19 \mathrm{~b}$ & n.d. \\
\hline $\mathrm{Cd}$ & & $24.18 \pm 0.84 b$ & $25.14 \pm 0.87 \mathrm{~b}$ & $36.37 \pm 0.74 \mathrm{a}$ & $35.73 \pm 1.43 \mathrm{a}$ \\
\hline $\mathrm{Mg}$ & & \multicolumn{4}{|c|}{$<1500$} \\
\hline $\mathbf{P}$ & & \multicolumn{4}{|c|}{$<200$} \\
\hline
\end{tabular}

n.d. = Not detected. Different letters $(a, b, c \ldots)$ indicate significant differences, of each parameter among the different experimental fields $(p \leq 0.05)$. 


\subsection{Zinc Contents and Deposition in Grain Tissues}

In each experimental field, $\mathrm{Zn}$ contents in the whole wheat grains showed higher values in Roxo (Table 2), with the highest values being found in T2 (except for fields 1 and 4-Zn-EDTA with T1 showing the highest value, although only significant in field 1). In all treatments, Paiva further systematically showed the lowest $\mathrm{Zn}$ content in T0. In field 4, the highest $\mathrm{Zn}$ content was found after application of $\mathrm{ZnSO}_{4}$ in T2 (Roxo) and the lowest in T0 of Paiva. Among the wheat fields, T0 of Roxo only showed a significant higher Zn content in field 3, whereas T1 prevailed in fields 1 and 4, followed by fields 3 and 2, and T2 showed the highest content in field $4\left(\mathrm{ZnSO}_{4}\right)$, followed by fields 4 (Tecnifol Zinc) and 1 and fields 2 and 4 (Zn-EDTA). Relative to T0 of Paiva, field 3 showed the highest $Z n$ contents, followed by fields $4\left(\mathrm{ZnSO}_{4}\right), 2$ and 4 (Zn-EDTA) and therefore fields 4 (Tecnifol Zinc) and 1, whereas T1 prevails in fields 1 and 4, followed for 3 and 2, and in T2 the highest values were found in field $4\left(\mathrm{ZnSO}_{4}\right)$, followed by field 3 and fields 4 (Tecnifol Zinc), 2 and finally field 1. Moreover, it was interesting to notice that in all fields $\mathrm{Zn}$ contents in Roxo and Paiva grains (Figure $1 \mathrm{~A}, \mathrm{~B}$ ) showed trendlines following a similar order of decreasing accumulation kinetics: $4\left(\mathrm{ZnSO}_{4}\right)>4$ (Tecnifol Zinc) $>4(\mathrm{Zn}$-EDTA $)>1\left(\mathrm{ZnSO}_{4}\right)>2(\mathrm{Zn}-\mathrm{EDTA})>3$ (Tecnifol Zinc). Besides, under similar soil characteristics (i.e., field 4), for both varieties, the highest kinetics for $\mathrm{Zn}$ accumulation occurred with $\mathrm{ZnSO}_{4}$, whereas Tecnifol Zinc and $\mathrm{Zn}$-EDTA reversed their position relative to fields 2 and 3 .

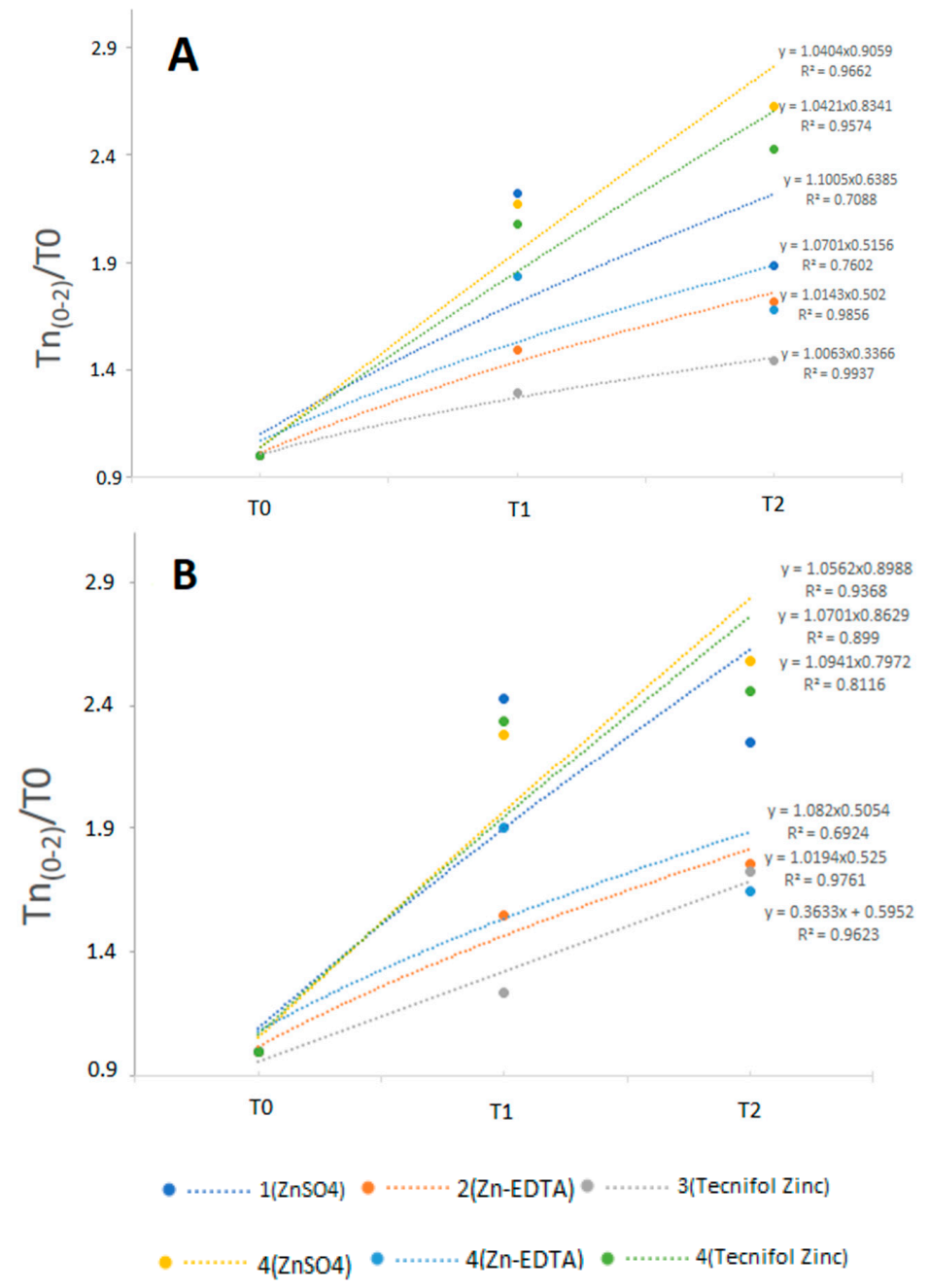

Figure 1. Ratio between the average value of $\mathrm{Zn}$ concentration in each treatment and the control (T0), as well as the relative trend line for all the wheat fields of Roxo (A) and Paiva varieties (B). Average values of $\mathrm{Zn}$ concentrations and trend lines of each wheat field are expressed in circles and lines. 
Table 2. Average $\mathrm{Zn}$ contents $\pm \mathrm{SE}(n=12)$ of whole wheat flour of Triticum aestivum L., varieties Roxo and Paiva, from experimental fields 1-4, after fertilization $\mathrm{ZnSO}_{4}, \mathrm{Zn}$-EDTA and Tecnifol Zinc.

\begin{tabular}{|c|c|c|c|c|c|c|c|}
\hline \multirow{4}{*}{ Variety } & \multirow{4}{*}{ Treatment } & \multicolumn{6}{|c|}{ Experimental Field/Fertilizer } \\
\hline & & 1 & 2 & 3 & \multicolumn{3}{|c|}{4} \\
\hline & & $\mathrm{ZnSO}_{4}$ & Zn-EDTA & Tecnifol Zinc & $\mathrm{ZnSO}_{4}$ & Zn-EDTA & Tecnifol Zinc \\
\hline & & \multicolumn{6}{|c|}{ Zn Contents (mg/kg) } \\
\hline \multirow{3}{*}{ Roxo } & T0 & $64.16 \pm 2.516^{\mathrm{d}, \mathrm{B}}$ & $53.99 \pm 1.270^{\mathrm{d}, \mathrm{B}}$ & $78.52 \pm 3.298^{\mathrm{cd}, A}$ & $59.99 \pm 1.537$ fghi, $\mathrm{B}$ & $54.16 \pm 2.280 \mathrm{hi}, \mathrm{B}$ & $51.96 \pm 5.479 \mathrm{hi}, \mathrm{B}$ \\
\hline & T1 & $142.5 \pm 4.556^{\mathrm{a}, \mathrm{A}}$ & $80.60 \pm 3.189 b c, C$ & $101.4 \pm 1.277^{\mathrm{b}, \mathrm{AB}}$ & $130.2 \pm 2.577^{\mathrm{abc}, \mathrm{AB}}$ & $99.57 \pm 18.26^{\text {cde, } \mathrm{AB}}$ & $107.9 \pm 2.974^{\text {bcde }, \mathrm{AB}}$ \\
\hline & $\mathrm{T} 2$ & $120.8 \pm 3.386^{\mathrm{b}, \mathrm{BC}}$ & $92.79 \pm 1.687^{\mathrm{a}, \mathrm{D}}$ & $113.1 \pm 1.399^{a, c}$ & $157.8 \pm 5.355^{\mathrm{a}, \mathrm{A}}$ & $90.95 \pm 2.367^{\text {defg, } \mathrm{D}}$ & $126.1 \pm 0.785^{\mathrm{abcd}, \mathrm{B}}$ \\
\hline \multirow{3}{*}{ Paiva } & T0 & $38.80 \pm 1.138^{\mathrm{e}, \mathrm{D}}$ & $50.44 \pm 2.018^{\mathrm{d}, \mathrm{B}}$ & $69.21 \pm 3.446^{\mathrm{d}, \mathrm{A}}$ & $55.07 \pm 1.372$ ghi, $\mathrm{B}$ & $48.72 \pm 1.892 \mathrm{hi}, \mathrm{BC}$ & $41.34 \pm 1.499^{\mathrm{i}, \mathrm{CD}}$ \\
\hline & T1 & $94.11 \pm 3.884^{\mathrm{c}, \mathrm{AB}}$ & $77.94 \pm 2.659^{\mathrm{c}, \mathrm{B}}$ & $85.73 \pm 1.003^{\mathrm{c}, \mathrm{B}}$ & $125.7 \pm 7.887^{\mathrm{abcd}, \mathrm{A}}$ & $92.67 \pm 17.67$ def, $\mathrm{AB}$ & $96.65 \pm 10.84^{\mathrm{cde}, \mathrm{AB}}$ \\
\hline & T2 & $87.39 \pm 7.799 \mathrm{c}, \mathrm{CD}$ & $88.58 \pm 0.842^{a b, C D}$ & $119.5 \pm 1.810^{\mathrm{a}, \mathrm{B}}$ & $142.2 \pm 3.011^{\mathrm{ab}, \mathrm{A}}$ & $80.28 \pm 1.068^{\text {efgh, } \mathrm{D}}$ & $101.6 \pm 2.696^{\mathrm{cde}, \mathrm{C}}$ \\
\hline
\end{tabular}

For the same fertilizer $\left(\mathrm{ZnSO}_{4}, \mathrm{Zn}\right.$-EDTA and Tecnifol Zinc): $\mathrm{T} 0=$ control; $\mathrm{T} 1, \mathrm{~T} 2$ correspond, respectively, to initial and upper concentration. Letters $a, b, c \ldots$ indicate significant differences of $Z n$ contents in the whole wheat flour among treatments within the same experimental field and letters A, B, C ... indicate significant differences of $\mathrm{Zn}$ contents in the whole wheat flour for the same treatment among the different experimental fields $(p \leq 0.05)$.

At harvest, Zn contents on the mature grain of both varieties in general increased as the application of $\mathrm{Zn}$ fertilizer had risen, being preferably located in the embryo and vascular bundle and less accumulated in aleurone (Figure 2).

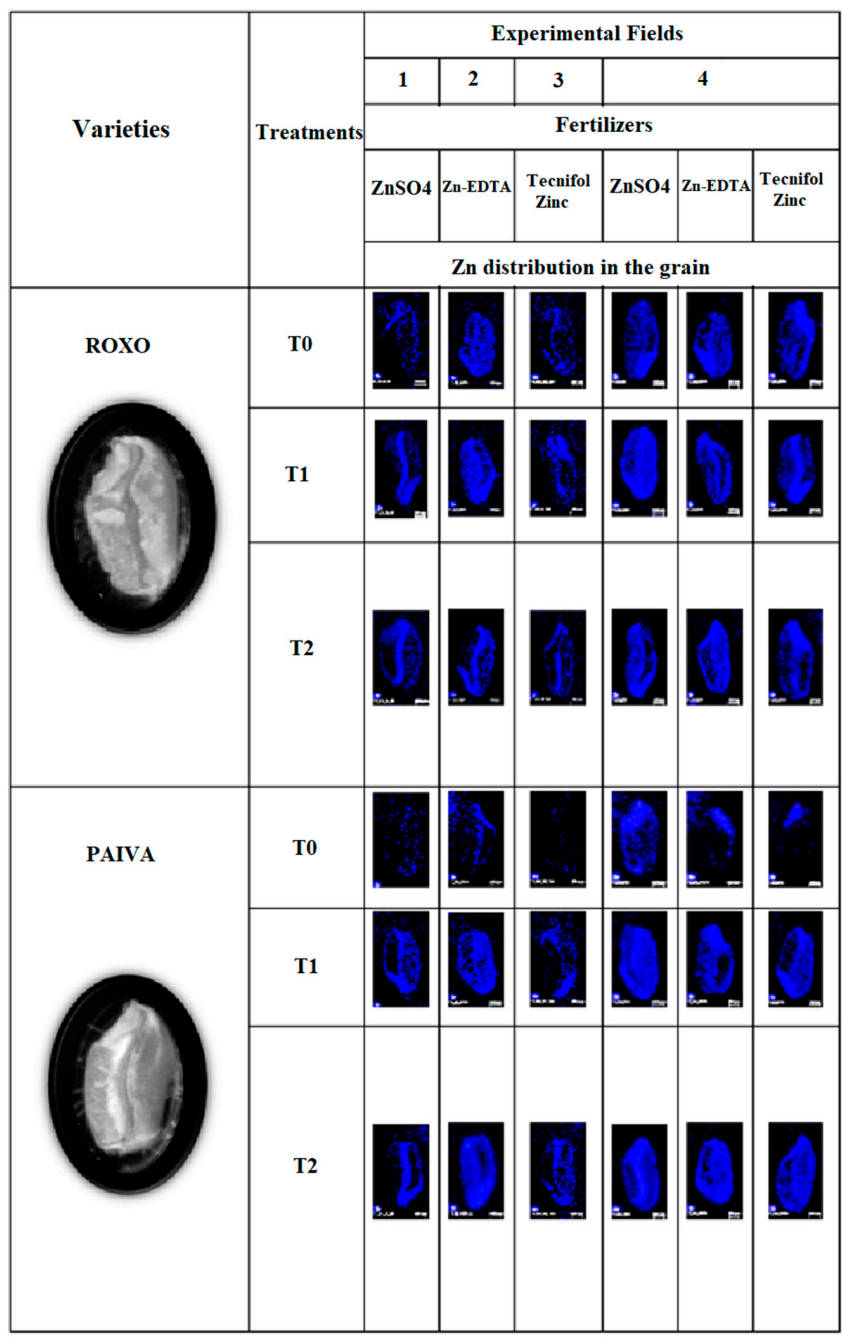

Figure 2. Elemental maps of Triticum aestivum L. grains, of Roxo and Paiva varieties, from the experimental fields 1-4, with the spatial distribution of $\mathrm{Zn}$ (in blue) in layered images. For the same fertilizer $\left(\mathrm{ZnSO}_{4}, \mathrm{Zn}\right.$-EDTA and Tecnifol Zinc): T0 = control; T1, T2 correspond, respectively, to initial and upper concentration. 


\subsection{Grain Yield, Test Weight, Thousand Kernel Weight, Moisture and Macroscopic Aspects}

Independent of each treatment, relative to Roxo, in fields 1 and 3 significantly higher grain yields were found in Paiva, after application of $\mathrm{ZnSO}_{4}$ and Tecnifol Zinc, respectively (Table 3). Moreover, in field 2, using Zn-EDTA as a fertilizer, significant differences could not be found among treatments for both varieties. In field 4 , among treatments, after application of $\mathrm{ZnSO}_{4}$ and Tecnifol Zinc, Paiva showed significantly higher grain yields (except $\mathrm{T} 2$ and $\mathrm{T} 1$ with $\mathrm{ZnSO}_{4}$ and Tecnifol Zinc, respectively). In each variety and experimental field, significant differences were not found among treatments.

Table 3. Grain Yield, Test Weight, Moisture Content and Thousand Kernel Weight (TKW) $(n=4)$ of Triticum aestivum L. grains, varieties Roxo and Paiva, from 1-4 experimental fields.

\begin{tabular}{|c|c|c|c|c|c|c|c|}
\hline $\begin{array}{l}\text { Experimental } \\
\text { Field }\end{array}$ & Fertilizer & Variety & Treatment & $\begin{array}{l}\text { Grain Yield } \\
\text { (kg/ha) }\end{array}$ & $\begin{array}{l}\text { Test Weight } \\
(\mathrm{kg} / \mathrm{hl})\end{array}$ & $\begin{array}{c}\text { Moisture Content } \\
(\%)\end{array}$ & TKW (g) \\
\hline \multirow{6}{*}{1} & \multirow{6}{*}{$\mathrm{ZnSO}_{4}$} & \multirow{4}{*}{ Roxo } & T0 & $1970 \pm 143^{\mathrm{b}, \mathrm{AB}}$ & $81.53 \pm 0.15^{a b, A}$ & $10.63 \pm 0.03^{a b, B}$ & $38.73 \pm 0.45^{\mathrm{a}, \mathrm{AB}}$ \\
\hline & & & T1 & $1932 \pm 58^{\mathrm{b}, \mathrm{A}}$ & $82.33 \pm 1.10^{a b, A}$ & $10.38 \pm 0.21 \mathrm{~b}, \mathrm{~B}$ & $34.30 \pm 1.42^{\mathrm{b}, \mathrm{B}}$ \\
\hline & & & $\mathrm{T} 2$ & $1841 \pm 82^{\mathrm{b}, \mathrm{A}}$ & $80.78 \pm 0.40^{\mathrm{b}, \mathrm{A}}$ & $10.62 \pm 0.08^{\mathrm{ab}, \mathrm{B}}$ & $33.39 \pm 1.34^{\mathrm{b}, \mathrm{B}}$ \\
\hline & & & T0 & $3379 \pm 78^{\mathrm{a}, \mathrm{A}}$ & $83.35 \pm 0.30^{\mathrm{a}, \mathrm{A}}$ & $10.66 \pm 0.08^{a b, B}$ & $42.69 \pm 0.46^{\mathrm{a}, \mathrm{AB}}$ \\
\hline & & \multirow[t]{2}{*}{ Paiva } & T1 & $3002 \pm 256^{\mathrm{a}, \mathrm{A}}$ & $82.10 \pm 0.30^{a b, A}$ & $10.91 \pm 0.02^{\mathrm{a}, \mathrm{B}}$ & $41.09 \pm 0.74^{\mathrm{a}, \mathrm{A}}$ \\
\hline & & & $\mathrm{T} 2$ & $3050 \pm 117^{\mathrm{a}, \mathrm{A}}$ & $82.13 \pm 0.30^{a b, A}$ & $10.87 \pm 0.05^{\mathrm{a}, \mathrm{C}}$ & $41.67 \pm 0.45^{\mathrm{a}, \mathrm{A}}$ \\
\hline \multirow{6}{*}{2} & \multirow{6}{*}{ Zn-EDTA } & \multirow{4}{*}{ Roxo } & T0 & $1691 \pm 152^{a, B}$ & $81.78 \pm 0.14^{\mathrm{a}, \mathrm{A}}$ & $10.34 \pm 0.06^{\mathrm{a}, \mathrm{B}}$ & $39.43 \pm 0.92^{\mathrm{ab}, \mathrm{AB}}$ \\
\hline & & & T1 & $1559 \pm 217^{\mathrm{a}, \mathrm{A}}$ & $80.18 \pm 0.84^{\mathrm{a}, \mathrm{AB}}$ & $10.28 \pm 0.03^{a, B}$ & $40.05 \pm 1.23 \mathrm{ab}, \mathrm{A}$ \\
\hline & & & T2 & $1621 \pm 153^{\mathrm{a}, \mathrm{A}}$ & $79.35 \pm 1.52^{\mathrm{a}, \mathrm{AB}}$ & $10.26 \pm 0.04^{\mathrm{a}, \mathrm{B}}$ & $36.56 \pm 1.41^{\mathrm{b}, \mathrm{AB}}$ \\
\hline & & & T0 & $1572 \pm 61^{\mathrm{a}, \mathrm{C}}$ & $80.38 \pm 0.21^{\mathrm{a}, \mathrm{B}}$ & $10.29 \pm 0.03^{\mathrm{a}, \mathrm{C}}$ & $41.08 \pm 0.20^{\mathrm{a}, \mathrm{B}}$ \\
\hline & & \multirow[t]{2}{*}{ Paiva } & T1 & $1625 \pm 211^{\mathrm{a}, \mathrm{B}}$ & $79.13 \pm 0.54^{\mathrm{a}, \mathrm{B}}$ & $10.27 \pm 0.02^{a, C}$ & $41.02 \pm 0.53^{\mathrm{a}, \mathrm{A}}$ \\
\hline & & & $\mathbf{T} 2$ & $1472 \pm 122^{a, C}$ & $78.80 \pm 0.18^{\mathrm{a}, \mathrm{B}}$ & $10.17 \pm 0.04^{\mathrm{a}, \mathrm{D}}$ & $39.31 \pm 0.61^{\mathrm{ab}, \mathrm{AB}}$ \\
\hline \multirow{6}{*}{3} & \multirow{6}{*}{$\begin{array}{l}\text { Tecnifol } \\
\text { Zinc }\end{array}$} & \multirow{4}{*}{ Roxo } & T0 & $1689 \pm 107^{b, B}$ & $76.95 \pm 0.74^{\mathrm{ab}, \mathrm{B}}$ & $10.54 \pm 0.04^{b c, B}$ & $28.68 \pm 0.71^{\mathrm{c}, \mathrm{C}}$ \\
\hline & & & T1 & $1716 \pm 64^{\mathrm{b}, \mathrm{A}}$ & $78.13 \pm 0.33^{\mathrm{a}, \mathrm{B}}$ & $10.52 \pm 0.03^{b c, B}$ & $30.04 \pm 0.25^{b c, C}$ \\
\hline & & & T2 & $1594 \pm 62^{\mathrm{b}, \mathrm{A}}$ & $76.95 \pm 0.63^{a b, B}$ & $10.49 \pm 0.09^{\mathrm{c}, \mathrm{B}}$ & $28.87 \pm 0.85^{c, C}$ \\
\hline & & & T0 & $2902 \pm 123^{\mathrm{a}, \mathrm{AB}}$ & $74.58 \pm 0.69 \mathrm{bc}, \mathrm{C}$ & $10.75 \pm 0.04^{\mathrm{ab}, \mathrm{B}}$ & $34.76 \pm 0.56^{a, C}$ \\
\hline & & \multirow[t]{2}{*}{ Paiva } & T1 & $2594 \pm 232^{\mathrm{a}, \mathrm{A}}$ & $73.78 \pm 0.70^{c, C}$ & $10.79 \pm 0.06^{\mathrm{a}, \mathrm{B}}$ & $34.30 \pm 1.91^{\mathrm{ab}, \mathrm{B}}$ \\
\hline & & & $\mathrm{T} 2$ & $2810 \pm 157^{a, A}$ & $75.08 \pm 0.05^{b c, C}$ & $10.68 \pm 0.04^{a b c, C}$ & $33.70 \pm 0.66^{a b, C}$ \\
\hline \multirow{18}{*}{4} & \multirow{7}{*}{$\mathrm{ZnSO}_{4}$} & \multirow{4}{*}{ Roxo } & T0 & $2349 \pm 151$ cdef,A & $82.7 \pm 0.24^{\mathrm{ab}, \mathrm{A}}$ & $11.41 \pm 0.19$ bcd,A & $42.35 \pm 0.68^{\mathrm{ab}, \mathrm{A}}$ \\
\hline & & & T1 & $1915 \pm 113^{\mathrm{fg}, \mathrm{A}}$ & $82.10 \pm 0.30 \mathrm{ab}, \mathrm{A}$ & $11.33 \pm 0.13^{\mathrm{cd}, \mathrm{A}}$ & $39.97 \pm 0.69$ bcde,A \\
\hline & & & $\mathrm{T} 2$ & $1626 \pm 142^{g, A}$ & $81.90 \pm 0.36^{\mathrm{ab}, \mathrm{A}}$ & $11.58 \pm 0.18^{\text {abcd, } \mathrm{A}}$ & $38.46 \pm 0.62$ cdef, $\mathrm{A}$ \\
\hline & & & T0 & $3180 \pm 185^{a b, A}$ & $82.45 \pm 0.44^{\mathrm{ab}, \mathrm{A}}$ & $12.00 \pm 0.06^{\mathrm{ab}, \mathrm{A}}$ & $41.19 \pm 0.60 \mathrm{abc}, \mathrm{B}$ \\
\hline & & \multirow[t]{3}{*}{ Paiva } & T1 & $3234 \pm 109^{\mathrm{a}, \mathrm{A}}$ & $82.53 \pm 0.23^{a b, A}$ & $11.91 \pm 0.08^{\mathrm{abcd}, \mathrm{A}}$ & $42.47 \pm 0.32^{\mathrm{ab}, \mathrm{A}}$ \\
\hline & & & $\mathrm{T} 2$ & $3047 \pm 94 a b c, A$ & $82.50 \pm 0.29 \mathrm{ab}, \mathrm{A}$ & $11.70 \pm 0.06^{\mathrm{abcd}, \mathrm{B}}$ & $37.78 \pm 1.14{ }^{\text {cdef, } \mathrm{B}}$ \\
\hline & & & T0 & $1902 \pm 6^{\mathrm{fg}, \mathrm{AB}}$ & $82.78 \pm 0.19 \mathrm{ab}, \mathrm{A}$ & $11.49 \pm 0.14^{\mathrm{abcd}, \mathrm{A}}$ & $36.61 \pm 0.90^{\mathrm{ef}, \mathrm{B}}$ \\
\hline & \multirow{4}{*}{ Zn-EDTA } & \multirow[t]{3}{*}{ Roxo } & T1 & $1799 \pm 122 \mathrm{fg}, \mathrm{A}$ & $82.45 \pm 0.36^{\mathrm{ab}, \mathrm{A}}$ & $11.29 \pm 0.11^{\mathrm{d}, \mathrm{A}}$ & $35.25 \pm 0.51^{\mathrm{f}, \mathrm{B}}$ \\
\hline & & & $\mathrm{T} 2$ & $1573 \pm 44^{\mathrm{g}, \mathrm{A}}$ & $81.75 \pm 0.21 \mathrm{~b}, \mathrm{~A}$ & $11.39 \pm 0.04$ bcd,A & $36.19 \pm 0.76^{\mathrm{f}, \mathrm{AB}}$ \\
\hline & & & T0 & $2452 \pm 171^{\text {cdef,B }}$ & $82.98 \pm 0.28^{a b, A}$ & $11.89 \pm 0.09^{\mathrm{abcd}, \mathrm{A}}$ & $43.06 \pm 0.67^{\mathrm{ab}, \mathrm{AB}}$ \\
\hline & & \multirow[t]{3}{*}{ Paiva } & T1 & $2495 \pm 99$ bcdef,A & $82.70 \pm 0.16^{\mathrm{ab}, \mathrm{A}}$ & $11.66 \pm 0.14^{\mathrm{abcd}, \mathrm{A}}$ & $42.23 \pm 0.38^{\mathrm{ab}, \mathrm{A}}$ \\
\hline & \multirow{7}{*}{$\begin{array}{l}\text { Tecnifol } \\
\text { Zinc }\end{array}$} & & $\mathrm{T} 2$ & $2203 \pm 191$ defg, $\mathrm{B}$ & $82.18 \pm 0.28^{a b, A}$ & $11.88 \pm 0.08^{a b c d, A B}$ & $40.81 \pm 0.66^{\mathrm{bcd}, \mathrm{AB}}$ \\
\hline & & & T0 & $2077 \pm 122$ efg, $\mathrm{AB}$ & $82.73 \pm 0.20^{a b, A}$ & $11.64 \pm 0.13^{\mathrm{abcd}, \mathrm{A}}$ & $35.66 \pm 1.21^{\mathrm{f}, \mathrm{B}}$ \\
\hline & & \multirow[t]{2}{*}{ Roxo } & T1 & $1951 \pm 168^{\mathrm{fg}, \mathrm{A}}$ & $81.90 \pm 0.17^{\mathrm{ab}, \mathrm{A}}$ & $11.62 \pm 0.15^{\mathrm{abcd}, \mathrm{A}}$ & $37.46 \pm 0.77^{\text {def, }} \mathrm{AB}$ \\
\hline & & & $\mathrm{T} 2$ & $1831 \pm 155^{\mathrm{fg}, \mathrm{A}}$ & $82.40 \pm 0.10^{\mathrm{ab}, \mathrm{A}}$ & $11.44 \pm 0.14^{\mathrm{abcd}, \mathrm{A}}$ & $36.82 \pm 0.28^{\text {ef, }} \mathrm{AB}$ \\
\hline & & \multirow{3}{*}{ Paiva } & T0 & $2827 \pm 217^{\mathrm{abcd}, \mathrm{AB}}$ & $83.30 \pm 0.33^{\mathrm{a}, \mathrm{A}}$ & $11.77 \pm 0.13^{\mathrm{abcd}, \mathrm{A}}$ & $44.52 \pm 0.13^{\mathrm{a}, \mathrm{A}}$ \\
\hline & & & T1 & $2731 \pm 125^{\text {abcde, } \mathrm{A}}$ & $82.88 \pm 0.31^{a b, A}$ & $11.93 \pm 0.15^{\mathrm{abc}, \mathrm{A}}$ & $42.96 \pm 0.31^{\mathrm{ab}, \mathrm{A}}$ \\
\hline & & & T2 & $2808 \pm 65^{\mathrm{abcd}, \mathrm{A}}$ & $82.80 \pm 0.21^{\mathrm{ab}, \mathrm{A}}$ & $12.07 \pm 0.03^{\mathrm{a}, \mathrm{A}}$ & $42.20 \pm 0.56^{\mathrm{ab}, \mathrm{A}}$ \\
\hline
\end{tabular}

For the same fertilizer $\left(\mathrm{ZnSO}_{4}, \mathrm{Zn}-\mathrm{EDTA}\right.$ and Tecnifol Zinc): T0 = control; T1, T2 correspond, respectively, to initial and upper concentration. Letters $a, b, c \ldots$ indicate, within each item, significant differences among treatments, for both varieties in the same experimental field and letters A, B, C ... indicate, within each item, significant differences among each treatment, for each variety and among all experimental fields $(p \leq 0.05)$.

Test weight only showed significantly lower values in T2 of Roxo (field 1), T1 of Paiva (only relatively to all treatments in Roxo of field 3) and T2 of Roxo (field 4-Zn-EDTA), whereas Paiva revealed significantly higher values relative to T2 of Roxo (field $4-\mathrm{Zn}$ EDTA) (Table 3). In each variety and experimental field, significant differences could not be found. 
In field 1, moisture content was significantly lower for T1 of Roxo (relatively to T1 and T2 of Paiva), whereas in field 3 significantly lower and higher values were found for T2 of Roxo (only relatively to T1 of Paiva) and T1 of Paiva (only relatively to all treatments of Roxo), respectively (Table 3). Significant variations could not be found in field 2, for both varieties and treatments. In field 4, after application of $\mathrm{ZnSO}_{4}$, significantly lower values were obtained for T1 of Roxo (relatively to T0 of Paiva), whereas after application of Zn-EDTA and Tecnifol Zinc, differences could not be found in the related treatments for both varieties.

In field 1, Thousand Kernel Weight (TKW) was significantly higher in all treatments of Paiva (although not for T0), whereas in field 2 the value for T2 remained lower for T2 of Roxo (but only significantly relatively to T0 e T1 of Paiva) (Table 3). In field 3, all treatments of Paiva remained significantly higher (except relatively to T1 of Roxo). In field 4, with $\mathrm{ZnSO}_{4}, \mathrm{~T} 0$ and $\mathrm{T} 1$ of Roxo and Paiva respectively showed significantly higher values for TKW, relative to the other treatments (except T0 in Paiva), whereas after application of Zn-EDTA or Tecnifol Zinc, all treatments of Paiva showed higher values relative to Roxo.

Considering all experimental fields, it was found that the grain yield of Roxo in field 4, after application of $\mathrm{ZnSO}_{4}$, showed the highest value for T0 (although only significant relative to T0 of fields 2 and 3, after application of Zn-EDTA and Tecnifol Zinc, respectively), but T1 and T2 did not vary significantly (Table 3). Relative to Paiva, the grain yield of T0 revealed the highest values in fields 1 and 4, with application of $\mathrm{ZnSO}_{4}$ (although only significant relatively to field 2 and 4 , with application of Zn-EDTA), whereas field 2 revealed the significantly lower value after application of Zn-EDTA, and T2 showed the lowest value in field 2, followed by field 4 (both treated with Zn-EDTA, being significantly different).

In field 1, test weight only varied significantly between the control of Paiva (revealing minimum values) and T2 of Roxo, whereas field 2 and 4 (with $\mathrm{ZnSO}_{4}$ spraying) did not vary significantly, and field 3 showed minimum values in Paiva (without significant differences among treatments) (Table 3). In field 4, after spraying with Zn-EDTA and Tecnifol Zinc, minimum and maximum values were found for T2 of Roxo and T0 of Paiva, respectively. In all the wheat fields, T0, T1, T2 of Roxo only revealed significantly lower values in field 3, whereas all these treatments of Paiva showed significantly lower values in fields 2 and 3.

In field 1, relative to T1 and T2 of Paiva, moisture showed significantly lower values in T1 of Roxo, whereas significant differences were not found in field 2 (Table 3). In field 3 , relative to $\mathrm{T} 0$ and $\mathrm{T} 1$, significantly lower values occurred in T2 of Roxo, while for T0 and T2 of field 4, minimum and maximum values were found in Roxo (Zn-EDTA) and Paiva (Tecnifol Zinc), respectively. In field 4, relative to fields 1, 2 and 3, independent of the applied fertilizer, Roxo showed significantly higher moisture for T0 and T2, whereas T1 did not vary significantly among the experimental fields. T0 (Control) of Paiva showed, relative to fields 1, 2 and 3, significantly higher moisture in field 4 (independently of the applied fertilizer), with field 2 displaying minimum values. A similar pattern occurred with T1, yet T2 revealed significantly lower values in field 2, followed by field 1 and 3 , whereas field 4 showed maximum values after application of Tecnifol Zinc.

Field 1 revealed minimum values of TKW for T1 and T2 of Roxo, whereas field 2 showed lower values for T2 of Paiva and, in field 3, higher values were found in all treatments of Paiva (Table 3). In field 4, T0 and T1 of Roxo and Paiva sprayed with $\mathrm{ZnSO}_{4}$ and T0, T1 and T2 of Paiva pulverized with Zn-EDTA and Tecnifol Zinc, did not vary significantly. All the remaining treatments of both varieties, submitted to the different fertilizers, did not vary significantly among them. Comparing the TKW of each treatment, in Roxo, among the different experimental fields, it was found that the lowest values of T0 occurred in field 4 (sprayed with Zn-EDTA and Tecnifol Zinc), whereas the highest were found in fields 1, 2 and 4 (pulverized with $\mathrm{ZnSO}_{4}$ ). Moreover, in Roxo, T1 kept the highest values in fields 2 and 4 (sprayed with $\mathrm{ZnSO}_{4}$ ), followed by fields 1 and 4 (pulverized with Zn-EDTA) and field 3. T2, of Roxo, revealed the highest values in field 4 (pulverized with $\mathrm{ZnSO}_{4}$ ), followed by field 1, 2 and 4 (sprayed with Zn- EDTA and Tecnifol Zinc). Concerning Paiva, the highest values of TKW were found in field 1 and 4 (fertilized with 
Zn-EDTA and Tecnifol Zinc), whereas the lowest occurred in field 3. In Paiva, T1 showed the highest values in fields 1, 2 and 4 (with all fertilizers), whereas T2 revealed the highest values in fields 1 and 4 (sprayed with Tecnifol Zinc) and the lowest in field 3.

At a macroscopic level, visual symptoms of grains deficiency or toxicity (i.e., deformed or shrunken) could not be found among treatments in each experimental field or genotype (Figure 3).

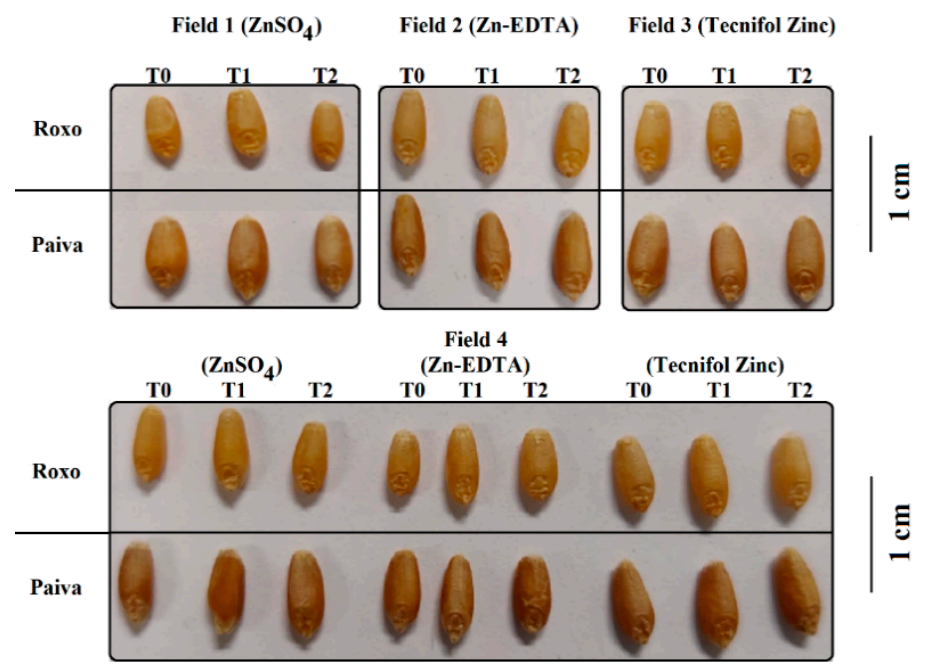

Figure 3. Macroscopic aspects of Triticum aestivum L. grains, of each treatment of Roxo and Paiva varieties, from the experimental fields $1-4$. For the same fertilizer $\left(\mathrm{ZnSO}_{4}, \mathrm{Zn}\right.$-EDTA and Tecnifol Zinc): T0 = control; T1, T2 correspond, respectively, to initial and upper concentration.

\subsection{Ash Contents and Colorimetric Parameters of Whole Wheat Flour}

In field 2, ash content of whole wheat flour did not vary significantly among treatments of both varieties and, in field 3, only T0 of Roxo varied significantly (Table 4). In field 1, ash showed significantly higher and lower values in T0 and T2 of Paiva, whereas in field 4 Roxo presented for T0, T1 and T2 significantly higher values and T1 and T2 of Paiva at the lowest levels. Among all T0 of Roxo, in all the experimental fields, the trend of ash content was fields 3 and $4\left(\mathrm{ZnSO}_{4}\right)>$ field $1>$ field $4(\mathrm{Zn}$-EDTA and Tecnifol Zinc) $>$ field 2, whereas for T1 were fields 1,3 and $4\left(\mathrm{ZnSO}_{4}\right)>$ field $4(\mathrm{Zn}$-EDTA and Tecnifol Zinc) $>$ field 2 and for T2 were fields $4\left(\mathrm{ZnSO}_{4}\right)$ and $1>$ field 3 and 4 ( $\mathrm{Zn-EDTA} \mathrm{and} \mathrm{Tecnifol} \mathrm{Zinc)}$ $>$ field 2. Among all T0 of Paiva, in all the experimental fields, the trend of the ash content was field $1>$ fields 2, 3 and $4\left(\mathrm{ZnSO}_{4}\right.$ and $\left.\mathrm{Zn-EDTA}\right)>$ field 4 (Tecnifol Zinc), whereas in T1 it was fields 3 and $4\left(\mathrm{ZnSO}_{4}\right.$ and $\mathrm{Zn}$-EDTA) $>$ field $1>$ fields 2 and 4 (Tecnifol Zinc) and for T2 was fields 3 and $4\left(\mathrm{ZnSO}_{4}\right)>$ fields 1,2 and 4 (Zn-EDTA and Tecnifol Zinc).

Color parameters of whole wheat flour, among treatments, of Roxo and Paiva, from the different experimental fields, displayed significant variations (Table 4). In field 1, T0 and T2 of Paiva revealed the highest and the lowest values for $L^{*}$ (i.e., lightness), respectively. In field 2, $\mathrm{L}^{*}$ did not show significant variations for Zn-EDTA-treated Roxo and Paiva, whereas field 3 only revealed significantly higher values for T0 of Roxo. Field 4 revealed the highest values of $\mathrm{L}^{*}$ in Roxo treated with $\mathrm{ZnSO}_{4}$, whereas the lowest were detected with Tecnifol Zinc in both varieties and in Paiva sprayed with Zn-EDTA. Among all T0 of Roxo, in all the experimental fields, the trend of $\mathrm{L}^{*}$ was fields 1,2 and $4\left(\mathrm{ZnSO}_{4}\right.$ and Tecnifol Zinc) > fields 3 and 4 (Zn-EDTA), whereas for T1 and T2 it was fields 1, 2, and 4 $>$ field 3. Relative to Paiva, the trend of $L^{*}$ for T0 was fields 1,3 and $4>$ field 2, whereas for T1 it was fields 1 and $4>$ field $2>$ field 3 , and for T2 was fields 1,3 and $4>$ field 2 . In field 1, $\mathrm{a}^{*}$ (i.e., red-green transitions) revealed significant differences, for $\mathrm{T} 1$ of Paiva and T2 of Roxo showing the highest and lowest values, respectively. Fields 2 and 3 showed, relative to Roxo, the highest $\mathrm{a}^{*}$ values in all treatments of Paiva, whereas field 4 showed the significantly higher values for $\mathrm{T} 0$ sprayed with $\mathrm{ZnSO}_{4}$ and $\mathrm{Zn}$-EDTA and the lowest for 
$\mathrm{T} 0$ of Roxo $\left(\mathrm{ZnSO}_{4}\right)$ and for all treatments of Roxo (Zn-EDTA and Tecnifol Zinc). Among all T0 of Roxo, in all the experimental fields, the trend of a* was fields 1 and $3>$ field $4>$ field 2, whereas for T1 and T2 was fields 3 and $4>$ field $1>$ field 2 . Among all T0 of Paiva, in all the experimental fields, the trend of $\mathrm{a}^{*}$ was fields 2,3 and $4>$ field 1 , whereas for $\mathrm{T} 1$ it was fields 1, 2, 3, 4 (Zn-EDTA) $>$ field 4 ( $\mathrm{ZnSO}_{4}$ and Tecnifol Zinc), and for T2 it was fields 2, 3 and $4>$ field 1 . In field $1, b^{*}$ (i.e., yellow-blue transitions) revealed significant differences, for T0 and T1 of Paiva showing the lowest and highest values, respectively, whereas in field 2 significant differences could not be found. In field 3, for $\mathrm{b}^{*}$, only T0 of Roxo showed significantly higher values, whereas in field 4 the highest and the lowest significant values were found for T1 $\left(\mathrm{ZnSO}_{4}\right)$ of Roxo and T2 (Zn-EDTA) of Paiva. Among all T0 of Roxo, in all the experimental fields, the trend of $b^{*}$ was fields 1,3 and 4 (Zn-EDTA and Tecnifol Zinc) > fields 2 and $4\left(\mathrm{ZnSO}_{4}\right)$, whereas for T1 it was fields 1 and $4>$ field $3>$ field 2 , and for T2 it was fields 1, 3 and 4 ( $\mathrm{ZnSO}_{4}$ and Tecnifol Zinc) $>$ fields 2 and 4 (Zn-EDTA). Among all T0 of Paiva, in all the experimental fields, $b^{*}$ did not vary significantly, whereas the trend of $b^{*}$ for $\mathrm{T} 1$ it was fields 1 and $3>$ fields 2 and 4 , and for T2 it was fields 1,3 and 4 ( $\mathrm{ZnSO}_{4}$ and Tecnifol Zinc) $>$ fields 2 and 4 (Zn-EDTA). Through an analysis of cluster definition of color parameters, it was found that in each experimental field specific clusters were defined for parameters $L^{*}, a^{*}$ and $\mathrm{b}^{*}$ (Figure 4). For parameter $\mathrm{L}^{*}$ and $\mathrm{a}^{*}$, all wheat fields showed an individual cluster for each genotype. Moreover, parameter $\mathrm{b}^{*}$ showed individual clusters only in field 4 , whereas in fields 2 and 3 these were identified only for Paiva and in field 1 for Roxo.

Table 4. Ash Content $(n=3)$ and Colorimeter parameters-CIELab System $(n=12)$ of whole wheat flour of Triticum aestivum L., varieties Roxo and Paiva, from 1-4 experimental fields.

\begin{tabular}{|c|c|c|c|c|c|c|c|}
\hline \multirow{2}{*}{$\begin{array}{l}\text { Experimental } \\
\text { Field }\end{array}$} & \multirow{2}{*}{ Fertilizer } & \multirow{2}{*}{ Variety } & \multirow{2}{*}{ Treatment } & \multirow{2}{*}{ Ash Content (\%) } & \multicolumn{3}{|c|}{ Colorimeter-CIELab System } \\
\hline & & & & & $\mathbf{L}^{*}$ & $a^{*}$ & $\mathbf{b}^{*}$ \\
\hline \multirow{6}{*}{1} & \multirow{6}{*}{$\mathrm{ZnSO}_{4}$} & \multirow{4}{*}{ Roxo } & T0 & $1.839 \pm 0.030 \mathrm{bc}, \mathrm{B}$ & $81.67 \pm 0.610^{\mathrm{a}, \mathrm{AB}}$ & $-1.450 \pm 0.170^{\mathrm{bc}, \mathrm{AB}}$ & $22.48 \pm 0.370^{a b, A B}$ \\
\hline & & & T1 & $1.872 \pm 0.013^{\mathrm{b}, \mathrm{A}}$ & $82.33 \pm 0.340^{\mathrm{a}, \mathrm{A}}$ & $-1.900 \pm 0.070 \mathrm{c}, \mathrm{BC}$ & $22.45 \pm 0.270^{\mathrm{ab}, \mathrm{AB}}$ \\
\hline & & & $\mathrm{T} 2$ & $1.833 \pm 0.055^{\mathrm{bc}, \mathrm{AB}}$ & $82.61 \pm 0.460^{\mathrm{a}, \mathrm{A}}$ & $-1.950 \pm 0.090 \mathrm{c}, \mathrm{BC}$ & $21.97 \pm 0.250^{\mathrm{ab}, \mathrm{AB}}$ \\
\hline & & & T0 & $3.234 \pm 0.108^{\mathrm{a}, \mathrm{A}}$ & $77.55 \pm 1.670^{\mathrm{b}, \mathrm{A}}$ & $-1.190 \pm 0.190 \mathrm{ab}, \mathrm{B}$ & $20.90 \pm 0.630^{\mathrm{b}, \mathrm{A}}$ \\
\hline & & \multirow[t]{2}{*}{ Paiva } & T1 & $1.589 \pm 0.020 \mathrm{~cd}, \mathrm{BC}$ & $77.99 \pm 0.520^{\mathrm{b}, \mathrm{AB}}$ & $-0.760 \pm 0.190^{\mathrm{a}, \mathrm{AB}}$ & $22.77 \pm 0.460^{\mathrm{a}, \mathrm{A}}$ \\
\hline & & & $\mathrm{T} 2$ & $1.534 \pm 0.052 \mathrm{~d}, \mathrm{~B}$ & $79.48 \pm 0.580 \mathrm{ab}, \mathrm{A}$ & $-1.370 \pm 0.110 \mathrm{bc,B}$ & $21.23 \pm 0.140^{\mathrm{ab}, \mathrm{AB}}$ \\
\hline \multirow{6}{*}{2} & \multirow{6}{*}{ Zn-EDTA } & \multirow{3}{*}{ Roxo } & T0 & $1.480 \pm 0.030 \mathrm{a}, \mathrm{D}$ & $81.61 \pm 0.390^{\mathrm{a}, \mathrm{AB}}$ & $-2.040 \pm 0.040^{\mathrm{b}, \mathrm{C}}$ & $21.15 \pm 0.190^{\mathrm{a}, \mathrm{B}}$ \\
\hline & & & T1 & $1.600 \pm 0.046^{\mathrm{a}, \mathrm{C}}$ & $82.33 \pm 1.090^{\mathrm{a}, \mathrm{A}}$ & $-2.210 \pm 0.160^{b, c}$ & $20.66 \pm 0.420^{\mathrm{a}, \mathrm{C}}$ \\
\hline & & & $\mathrm{T} 2$ & $1.558 \pm 0.052^{\mathrm{a}, \mathrm{C}}$ & $82.91 \pm 0.730^{\mathrm{a}, \mathrm{A}}$ & $-2.130 \pm 0.180^{b, c}$ & $21.80 \pm 0.480^{\mathrm{a}, \mathrm{B}}$ \\
\hline & & \multirow{3}{*}{ Paiva } & T0 & $1.648 \pm 0.036^{\mathrm{a}, \mathrm{BC}}$ & $72.30 \pm 0.430^{\mathrm{b}, \mathrm{B}}$ & $-0.780 \pm 0.070^{\mathrm{a}, \mathrm{AB}}$ & $20.77 \pm 0.190^{\mathrm{a}, \mathrm{A}}$ \\
\hline & & & T1 & $1.522 \pm 0.034^{\mathrm{a}, \mathrm{C}}$ & $75.91 \pm 1.190^{\mathrm{b}, \mathrm{BC}}$ & $-1.000 \pm 0.110^{\mathrm{a}, \mathrm{AB}}$ & $21.09 \pm 0.130^{\mathrm{a}, \mathrm{B}}$ \\
\hline & & & $\mathrm{T} 2$ & $1.576 \pm 0.030^{\mathrm{a}, \mathrm{B}}$ & $74.59 \pm 1.300^{\mathrm{b}, \mathrm{B}}$ & $-0.820 \pm 0.160^{\mathrm{a}, \mathrm{A}}$ & $20.94 \pm 0.150^{\mathrm{a}, \mathrm{B}}$ \\
\hline \multirow{6}{*}{3} & \multirow{6}{*}{ Tecnifol Zinc } & \multirow{4}{*}{ Roxo } & T0 & $2.024 \pm 0.040^{\mathrm{a}, \mathrm{A}}$ & $79.30 \pm 0.400^{\mathrm{a}, \mathrm{B}}$ & $-1.080 \pm 0.130^{b c, A B}$ & $23.22 \pm 0.330^{\mathrm{a}, \mathrm{A}}$ \\
\hline & & & T1 & $1.811 \pm 0.018^{\mathrm{b}, \mathrm{A}}$ & $77.87 \pm 0.450^{a b, B}$ & $-1.590 \pm 0.090 \mathrm{c}, \mathrm{AB}$ & $21.71 \pm 0.170^{\mathrm{b}, \mathrm{BC}}$ \\
\hline & & & $\mathrm{T} 2$ & $1.814 \pm 0.023^{\mathrm{b}, \mathrm{B}}$ & $79.32 \pm 0.900^{\mathrm{a}, \mathrm{B}}$ & $-1.470 \pm 0.080^{c, A}$ & $22.13 \pm 0.160^{\mathrm{b}, \mathrm{AB}}$ \\
\hline & & & T0 & $1.785 \pm 0.027^{\mathrm{b}, \mathrm{BC}}$ & $76.09 \pm 0.620^{b c, A}$ & $-0.760 \pm 0.170^{\mathrm{ab}, \mathrm{AB}}$ & $21.44 \pm 0.390^{\mathrm{b}, \mathrm{A}}$ \\
\hline & & \multirow[t]{2}{*}{ Paiva } & T1 & $1.786 \pm 0.039 \mathrm{~b}, \mathrm{~A}$ & $73.48 \pm 0.860^{c, C}$ & $-0.530 \pm 0.130^{\mathrm{a}, \mathrm{A}}$ & $21.83 \pm 0.190^{\mathrm{b}, \mathrm{AB}}$ \\
\hline & & & $\mathrm{T} 2$ & $1.833 \pm 0.008^{\mathrm{b}, \mathrm{A}}$ & $77.93 \pm 0.650^{a b, A}$ & $-0.910 \pm 0.160^{\mathrm{ab}, \mathrm{AB}}$ & $21.79 \pm 0.190^{\mathrm{b}, \mathrm{A}}$ \\
\hline \multirow{18}{*}{4} & \multirow{7}{*}{$\mathrm{ZnSO}_{4}$} & \multirow{4}{*}{ Roxo } & T0 & $1.982 \pm 0.011^{\mathrm{a}, \mathrm{A}}$ & $80.88 \pm 0.240 \mathrm{abc}, \mathrm{AB}$ & $-1.680 \pm 0.130 \mathrm{ij}, \mathrm{BC}$ & $21.86 \pm 0.350$ bcdef,B \\
\hline & & & T1 & $1.890 \pm 0.006^{\mathrm{ab}, \mathrm{A}}$ & $80.39 \pm 0.490$ abcde, $\mathrm{A}$ & $-1.400 \pm 0.070$ defghi,A & $23.24 \pm 0.180^{\mathrm{a}, \mathrm{A}}$ \\
\hline & & & $\mathrm{T} 2$ & $1.999 \pm 0.032^{\mathrm{a}, \mathrm{A}}$ & $80.81 \pm 0.540^{\mathrm{abcd}, \mathrm{AB}}$ & $-1.460 \pm 0.140^{\text {efghi, } \mathrm{A}}$ & $23.15 \pm 0.380^{\mathrm{ab}, \mathrm{A}}$ \\
\hline & & & T0 & $1.846 \pm 0.007^{\mathrm{bc}, \mathrm{B}}$ & $76.43 \pm 0.280^{\mathrm{g}, \mathrm{A}}$ & $-0.630 \pm 0.090^{\mathrm{a}, \mathrm{A}}$ & $21.94 \pm 0.370$ abcde, $\mathrm{A}$ \\
\hline & & \multirow[t]{3}{*}{ Paiva } & T1 & $1.737 \pm 0.023^{\text {cde }, A}$ & $79.48 \pm 0.540$ bcdef, $\mathrm{A}$ & $-1.160 \pm 0.060$ bcdef, $\mathrm{B}$ & $21.08 \pm 0.070^{\mathrm{ef}, \mathrm{B}}$ \\
\hline & & & $\mathrm{T} 2$ & $1.782 \pm 0.027 \mathrm{bcd}, \mathrm{A}$ & $78.03 \pm 0.290$ efg, $\mathrm{A}$ & $-1.180 \pm 0.100$ bcdefg, $\mathrm{AB}$ & $21.08 \pm 0.340^{\mathrm{ef}, \mathrm{AB}}$ \\
\hline & & & T0 & $1.710 \pm 0.009$ def, $C$ & $79.65 \pm 1.190^{\text {bcdef, } \mathrm{B}}$ & $-1.570 \pm 0.100$ ghij,BC & $22.10 \pm 0.440^{\text {abcde }, \mathrm{AB}}$ \\
\hline & \multirow{5}{*}{ Zn-EDTA } & \multirow[t]{3}{*}{ Roxo } & T1 & $1.762 \pm 0.048^{\text {bcde, } \mathrm{AB}}$ & $79.88 \pm 0.420$ abcdef, $\mathrm{AB}$ & $-1.560 \pm 0.070$ fghij, $\mathrm{AB}$ & $22.44 \pm 0.290^{a b c d, A B}$ \\
\hline & & & $\mathrm{T} 2$ & $1.745 \pm 0.030^{\mathrm{cde}, \mathrm{B}}$ & $80.77 \pm 0.370$ abcd,AB & $-1.880 \pm 0.030$ hij, $\mathrm{ABC}$ & $\begin{array}{l}22.44 \pm 0.290 \\
21.66 \pm 0.310^{\text {cdef, } \mathrm{B}}\end{array}$ \\
\hline & & & T0 & $1.631 \pm 0.0322^{\text {efgh, } \mathrm{BC}}$ & $77.65 \pm 0.480 \mathrm{fg}, \mathrm{A}$ & $-0.650 \pm 0.080^{\mathrm{a}, \mathrm{A}}$ & $21.56 \pm 0.270$ cdef, $\mathrm{A}$ \\
\hline & & \multirow[t]{3}{*}{ Paiva } & T1 & $1.686 \pm 0.024$ defg, $\mathrm{AB}$ & $78.15 \pm 0.610$ defg, $\mathrm{AB}$ & $-0.900 \pm 0.040 \mathrm{abc}, \mathrm{AB}$ & $21.46 \pm 0.140$ def,B \\
\hline & & & $\mathrm{T} 2$ & $1.529 \pm 0.025^{\mathrm{h}, \mathrm{B}}$ & $79.30 \pm 0.240^{\text {bcdef, } \mathrm{A}}$ & $-1.230 \pm 0.020^{\text {cdefgh }, \mathrm{AB}}$ & $20.59 \pm 0.080^{\mathrm{f}, \mathrm{B}}$ \\
\hline & \multirow{6}{*}{ Tecnifol Zinc } & & T0 & $1.592 \pm 0.020 \mathrm{fgh}, \mathrm{CD}$ & $82.40 \pm 0.520 \mathrm{a}, \mathrm{A}$ & $-1.810 \pm 0.070 \mathrm{ij}, \mathrm{BC}$ & $22.11 \pm 0.140$ abcde, $\mathrm{AB}$ \\
\hline & & Roxo & T1 & $1.648 \pm 0.018^{\text {defgh, } \mathrm{BC}}$ & $81.63 \pm 0.470 \mathrm{abc}, \mathrm{A}$ & $-1.770 \pm 0.080 \mathrm{ij}, \mathrm{AB}$ & $22.49 \pm 0.280^{a b c d, A B}$ \\
\hline & & & $\mathrm{T} 2$ & $1.707 \pm 0.024^{\text {defg, }, \mathrm{BC}}$ & $81.97 \pm 0.360^{\mathrm{ab}, \mathrm{A}}$ & $-1.610 \pm 0.090^{\mathrm{j}, \mathrm{AC}}$ & $22.82 \pm 0.140 \mathrm{abc}, \mathrm{AB}$ \\
\hline & & & T0 & $1.572 \pm 0.028 \mathrm{gh}, \mathrm{C}$ & $77.53 \pm 0.720 \mathrm{fg}, \mathrm{A}$ & $-0.780 \pm 0.060^{\mathrm{ab}, \mathrm{AB}}$ & $21.42 \pm 0.160$ def,A \\
\hline & & Paiva & T1 & $1.522 \pm 0.027^{\mathrm{h}, \mathrm{C}}$ & $77.81 \pm 0.700^{\mathrm{efg}, \mathrm{AB}}$ & $-1.030 \pm 0.080^{\mathrm{abcd}, \mathrm{B}}$ & $21.39 \pm 0.240^{\text {def, } \mathrm{B}}$ \\
\hline & & & $\mathrm{T} 2$ & $1.529 \pm 0.028^{\mathrm{h}, \mathrm{B}}$ & $79.08 \pm 0.440^{\text {cdefg, }, A}$ & $-1.070 \pm 0.040^{\text {bcde }, \mathrm{AB}}$ & $21.84 \pm 0.210^{\text {bcdef, } \mathrm{A}}$ \\
\hline
\end{tabular}

For the same fertilizer $\left(\mathrm{ZnSO}_{4}, \mathrm{Zn}\right.$-EDTA and Tecnifol Zinc): T0 = control; T1, T2 correspond, respectively, to initial and upper concentration. Letters $a, b, c \ldots$ indicate, within each item, significant differences among treatments, for both varieties in the same experimental field and letters A, B, C . . indicate, within each item, significant differences among each treatment, for each variety and among all experimental fields $(p \leq 0.05)$. Color parameters: $\mathrm{L}^{*}$-lightness; $\mathrm{a}^{*}$-red-green transitions; $\mathrm{b}^{*}$ - yellow-blue transitions. 

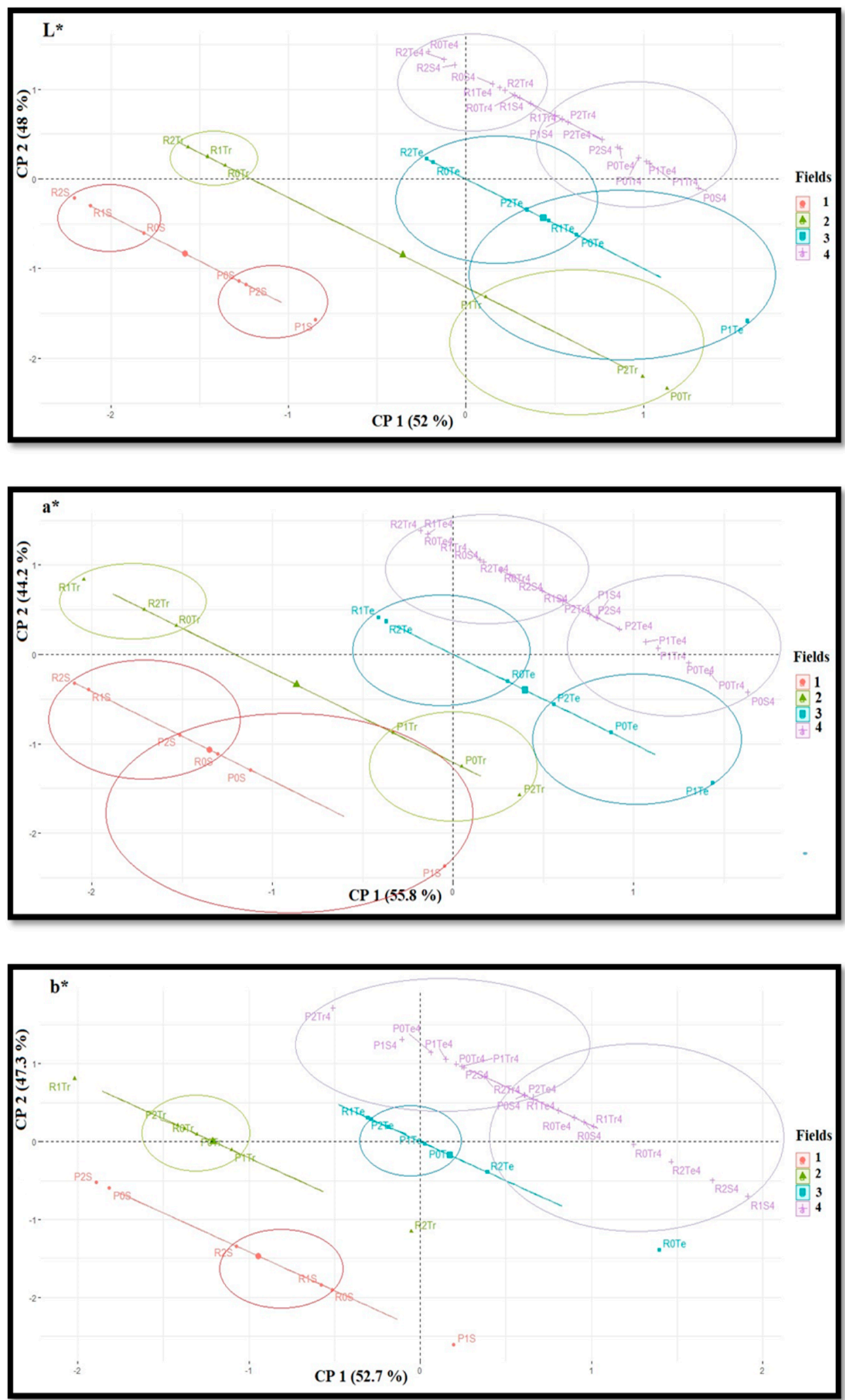

Figure 4. Attributes distribution formed by first and second principal components (CP 1 and CP 2, respectively) of colorimeter parameters $L^{*}, a^{*}$ and $b^{*}$-CIELab System $(n=12)$ of whole wheat flour, of fields 1, 2, 3 and 4 of Triticum aestivum L., varieties Roxo (R) and Paiva (P). Concentrations of treatments from the same fertilizer are divided into: control (0); C1 (1), C2 (2) corresponding, respectively, to an initial application and the upper application of the fertilizers $\mathrm{ZnSO}_{4}(\mathrm{~S}), \mathrm{Zn}^{\mathrm{E}} \mathrm{EDTA}$ (Tr) and Tecnifol Zinc (Te) (statistical analysis by software R version 3.6.3). 


\section{Discussion}

\subsection{Soil Aptitude for Zn Biofortification}

Crop biofortification must directly satisfy plants needs to produce healthy edible portions. Yet, the nutrient density of seed is dependent [38] on inherent fertility status, soil properties (namely organic, bioavailability of macro and micronutrients and moisture), crops species and cultivars (i.e., different genotypes can differ in phonological behavior and interaction due to genetic variation). Accordingly, four bread wheat fields were selected, to assess the interactions between nutrients contents, $\mathrm{pH}$, electrochemical conductivity and organic matter in soils, during Zn enrichment, taking into account that, depending on soil properties, wheat crop is estimated to remove a broad range of $\mathrm{Zn}$ (about 66-209 $\mathrm{g}$ of $\mathrm{Zn}$ for every 2 tons of wheat grains) [39].

Considering that $\mathrm{Zn}$ deficiencies (i.e., $\mathrm{Zn}$ content of unpolluted soils ranges between $10-80 \mathrm{mg} / \mathrm{kg}$ ) prevail in about $50 \%$ of soil samples collected worldwide $[40,41]$, the four experimental fields were further chosen to assess the implications of heterogeneous $\mathrm{Zn}$ contents in soils on the wheat grain biofortification index, which revealed notorious deviations (Table 2). Indeed, the kinetics of Zn uptake by roots was conditioned by significantly different contents of this nutrient in the soils of the four wheat fields (Table 1), which decreased in the following order: field $1>$ field $3>$ field $2>$ field 4 . Nevertheless, the bioavailability of $\mathrm{Zn}$ in soils is controlled by both absorption-desorption reactions and solubility relations, and the soil solution and solid phase are mainly involved in the absorption-desorption and dissolution precipitation reactions of $\mathrm{Zn}$ in soils [42]. Accordingly, low levels of $\mathrm{pH}$ (i.e., below 7) and organic matter in the soils augments Zn solubility and availability (as higher organic compounds in soils determines the synthesis of organic complexes), with low electrochemical conductivity, leading to shorter expenditure for water uptake by roots [21,43-45]. Therefore, considering these parameters, $\mathrm{Zn}$ uptake by roots in the wheat fields become favored according to the following trend: field $4>$ field $3>$ field $1=$ field 2 (Table 1). In addition, Ca and S display an antagonist effect on Zn solubility, since this nutrient uptake follows across the plasma, which covers root cells as $\mathrm{Zn}^{2+}[46]$, while it is also permeable to plasma membrane $\mathrm{Ca}^{2+}$ channels [47]. Moreover, the antagonistic interaction between $\mathrm{Zn}$ and $\mathrm{Fe}$, as well as with $\mathrm{Mn}$, favors the related oxides synthesis, triggering higher availability for root uptake [48]. Therefore, these soil interactions suggest a hold-up $\mathrm{Zn}$ availability in the wheat fields, according to the following trend: field $3>$ field $1>$ field $4>$ field 2 (Table 1 ). Moreover, although $\mathrm{K}$ contents showed the lowest values in fields 3 and 4, and $\mathrm{Cu}$ only showed significantly lower values in field 1 (Table 1), as their dynamics in soils depends on the magnitude of equilibrium among various chemical forms, a direct interaction on $\mathrm{Zn}$ availability is uncertain. A similar perspective applies to $\mathrm{Cd}$ and As, since the interactions with $\mathrm{Zn}$ for uptake and translocation in plants appears to be somewhat controversial [48-50], although Cd uptake might decrease with increasing Zn fertilization [51].

Considering all the studied soil determinants (Table 1), our data indicated that wheat field 3 showed the better edaphic conditions (although with the highest levels of organic matter, $\mathrm{pH}$ below 7, high $\mathrm{Zn}$, Fe and Mn contents and low values of $\mathrm{Ca}$ and $\mathrm{S}$ ). Thereafter, better conditions were found in field 1 (showing the highest contents of $\mathrm{Zn}$, high levels of $\mathrm{Fe}$ and $\mathrm{Mn}$ and the significantly lower amounts of organic matter, $\mathrm{Ca}$ and $\mathrm{S}$, but with $\mathrm{pH}$ higher than 7). Field 4 had worse edaphic conditions (in spite of $\mathrm{pH}$ below 7 and with the lowest amount of organic matter, with sharp limitations of $\mathrm{Zn}, \mathrm{Mn}$ and $\mathrm{Fe}$ ), followed by field 2 (revealing high contents of organic matter, low amounts of $\mathrm{Zn}$, Fe and $\mathrm{Mn}$ and the highest levels of $\mathrm{Ca}, \mathrm{S}$ and $\mathrm{pH}$ (Table 1)).

\subsection{Ash, Zinc Contents and Deposition in Grain Tissues}

Ash contents, as an indication of total nutrient concentration, did not reveal a positive correlation with $\mathrm{Zn}$ accumulation (Tables 2 and 4), which can mostly be attributed (in spite of the well-known relations with $\mathrm{Fe}$ and $\mathrm{Cu}$ uptake [52,53]) to heterogeneous interactions among macronutrients deposition in the grains of both genotypes. Thus, our data point 
out that nutrient deposition is closely linked with the heterogeneous characteristics of genotypes Roxo and Paiva (which determine different kinetics of root uptake) and specific characteristics of soils composition in the four bread wheat fields (Table 1). Indeed, it has long been known that Zn interacts positively, namely with $\mathrm{K}$, and negatively with $\mathrm{P}$ and $\mathrm{Ca}[52,53]$. Additionally, top dressing all the wheat fields with $\mathrm{N}$ also positively interacted with $\mathrm{Zn}$ magnification in the wheat grains by improving the grain protein amounts and thereby escalating the sink strength in grains for Zn [54]. Nevertheless, as Zn uptake is mostly controlled by its transport across the plasma membrane, which is largely metabolic-dependent and genetically controlled, Zn-efficient genotypes may be able to maintain structural and functional stability of their root-cell plasma membranes better than Zn-inefficient genotypes under Zn deficiency [55]. In this context, Zn accumulation in Roxo grains, which is an old variety, remained consistently higher, relative to the levels in the Paiva grains (Table 2), which agrees with [56]. Indeed, despite the breeding advances to increase grain yields, newly bred varieties are showing a limited capacity to enhance nutrient uptake efficiency [56].

Nutrient density per unit of grain dry weight is highly important for estimating grain quality [57]. Therefore, at critical growth stages of a crop, proper supply of micronutrients improves grain quality and the health status of human consumers [35]. Without $\mathrm{Zn}$ pulverization, this nutrient accumulation in the grain is only linked to its supply during developing, either by direct uptake from the soil through membrane bound transporters [58] followed by xylem loading and unloading and vacuolar sequestering and remobilization [59], or by remobilization from leaves. Accordingly, soil properties of the four wheat fields determined grain accumulation of $\mathrm{T} 0$ in both varieties only through $\mathrm{Zn}$ roots uptake kinetics (Tables 1 and 2). Additionally, due to the top dressing of all fields with N, root uptake and transport of $\mathrm{Zn}$, via chelation with nitrogenous compounds, improved proportionately $\mathrm{Zn}$ deposition in the grains, with N-levels [27]. In this context, as the control treatments (T0) of Roxo and Paiva genotypes were not sprayed with the $\mathrm{Zn}$ fertilizers, it was interesting to note that the highest accumulation of this nutrient in the grain correlated positively with soil properties of field 3 (Tables 1 and 2). Roxo grains of field 1 further showed the second highest $\mathrm{Zn}$ content, which therefore also interacted with soil properties. Additionally, field 4 and 2 showed similar values of $\mathrm{Zn}$ in the grain and again a positive relation was found. Facing $\mathrm{Zn}$ accumulation of Paiva grains in T0, field 1 revealed the lowest value, which suggested the prevalence of phenotype specificity, namely linking a decreased ratio between $\mathrm{Zn}$ uptake and higher grain yield (Table 3).

Zinc fertilization, which has high phloem mobility in wheat [60], is well-known to increase this nutrient accumulation in the grain and, consequently, the whole flour zinc concentration in wheat, either by soil or foliar application, or by combining soil and foliar zinc applications $[28,61,62]$. Yet, considering that the timing of a micronutrient foliar application delineates its effectiveness to increase grain contents, in our experiment, spraying with Zn-EDTA and Tecnifol Zinc occurred at booting, heading and grain milk stages, whereas pulverization with $\mathrm{ZnSO}_{4}$ took place only at booting and heading to avoid toxicity symptoms. Foliar $\mathrm{Zn}$ application, which is much effective than this nutrient application in the soil, triggered the highest kinetics of $\mathrm{Zn}$ accumulation in the grains of Roxo and Paiva under similar edaphic conditions (i.e., field 4). Accordingly, our data pointed that $\mathrm{ZnSO}_{4}$ is the best spraying fertilizer for wheat biofortification, whereas $\mathrm{Zn}$ EDTA is less effective (Figure 1). Therefore, our results do not support the report of [63], stating that the effective period for biofortification operation with $\mathrm{Zn}$ is the milking stage to the grain filling stage. However, with the report of [62], we found that, relative to $\mathrm{ZnSO}_{4}$, foliar spraying with Zn-EDTA resulted in lower values of zinc in grains $(32.3 \mathrm{mg} / \mathrm{kg}$ $\mathrm{ZnSO}_{4}$ and $29.0 \mathrm{mg} / \mathrm{kg}-\mathrm{Zn}$-EDTA), when $0.5 \mathrm{~kg} \mathrm{Zn} / \mathrm{ha}$ of $\mathrm{ZnSO}_{4}$ and $0.1 \mathrm{~kg} \mathrm{Zn} / \mathrm{ha}$ of Zn-EDTA were applied three times during the grain filling stage. Eventually, foliar spraying with Zn-EDTA is less effective than $\mathrm{ZnSO}_{4}$ because fertilizers have a distinct leaf penetration capacity, as Zn-EDTA has a carbon skeleton with higher dimensions [62]. Similarly [61], after spraying with 1.3, 2.2 and $3.0 \mathrm{~kg} / \mathrm{h}$ of $\mathrm{ZnSO}_{4} \cdot 7 \mathrm{H}_{2} \mathrm{O}$ during the wheat 
life cycle, we also found an enhancement of $\mathrm{Zn}$ concentration in the grains, which as a $\mathrm{Zn}$ foliar application is phloem-mobile, and might be a high capacity of translocation into wheat grains. Additionally, considering that the soil of field 4 had the lowest content of $\mathrm{Zn}$, being further limited by low organic matter and nutrient interactions (Table 1), our data indicated that the efficiency of $\mathrm{Zn}$ biofortification is largely determined by foliar fertilization (Table 1; Figure 1). Indeed, despite the soil characteristics of field 3, after spraying with Tecnifol Zinc, both genotypes had the lowest accumulation kinetics in the grains (Figure 1). Nevertheless, the highest efficiency of $\mathrm{Zn}$ spraying must also be linked to soils with high amounts of this nutrient to achieve the best biofortification index (Tables 1 and 2; Figure 1).

At harvest, $\mathrm{Zn}$ contents on the mature grain of both varieties was preferably located in the embryo and vascular bundle and less accumulated in aleurone (Figure 2), a pattern also reported by $[64,65]$. Thus, our data indicated that, for both genotypes, whole wheat flour enriched with $\mathrm{Zn}$ becomes a better option for human consumption because after milling Zn-rich parts (i.e., the aleurone and embryo) are mostly removed and only the endosperm remains, making refined wheat flour poorly $\mathrm{Zn}$-enriched.

\subsection{Grain Yield, Test Weight, Thousand Kernel Weight (TKW) and Colorimetric Parameters}

Despite the significantly different $\mathrm{Zn}$ contents in the soils of the four experimental fields, biofortified wheat grains did not reveal typical symptoms [66] of yield reduction (Table 3; Figure 3). Additionally, in all wheat fields, and therefore independent of the foliar fertilizer applied (Table 3), grain yield of each genotype did not show significant differences among treatments (except the control of Roxo in field 4), with Roxo showing a similar tendency to that reported by [28] after foliar spraying with $\mathrm{ZnSO}_{4} \cdot 7 \mathrm{H}_{2} \mathrm{O}$. We found in fields 2 and 4, as also [62], through pulverization with Zn-EDTA, further working with bread wheat, did not find significant differences of grain yield/test weight. Yet, $[61,67]$ it was found in an opposite trend for grain yield and TKW, which could be attributed to different growth conditions and genotype specificity. Nonetheless, following [68], in general, in both genotype top-dressings, all wheat fields with $\mathrm{N}$ boost both grain yield and protein amounts. Moreover, dry matter accumulation and yield attributing characters mostly differ when different cultivars were selected based on their genotypic sequencing. Indeed, independent of each treatment, the consistently higher values of grain yield of Paiva, relatively to Roxo, found in fields 1, 3 and 4 (except T2 and T1 with $\mathrm{ZnSO}_{4}$ and Tecnifol Zinc, respectively), through pulverization with $\mathrm{ZnSO}_{4}$ and Tecnifol Zinc, was the result of wheat breeding (i.e., Roxo and Paiva are old and modern varieties, respectively). Paiva was developed for achieving higher grain weight and TKW. Nevertheless, independent of the edaphic characteristics of the experimental fields, and although in most treatments significant differences could not be found, the highest grain yield was obtained through pulverization of Roxo and Paiva with $\mathrm{ZnSO}_{4}$, whereas foliar spraying with $\mathrm{Zn}$-EDTA consistently gave the lowest values (Table 3 ). Besides, to some extent, similar trends were also found for test weight moisture content and TKW.

To assess agricultural crop yield, relative to the environmental and technological factors such as fertilizer dosage, imagery techniques can be used. Following the system of the Comission Internationale d'Éclaire (CIE), a correlation between Zn enrichment and the color parameters $\mathrm{L}^{*}, \mathrm{a}^{*}$ or $\mathrm{b}^{*}$ could not be found (Table 4), as in spite of the variations detected in fields 1, 2 and 3, these were not confirmed in field 4 . Moreover, in each experimental field, individual clusters were found (Figure 4), which indicated that the conjunction of edaphic characteristics and types of foliar fertilizers can define specific patterns of $\mathrm{L}^{*}$ and $\mathrm{a}^{*}$ parameters for both genotypes.

\section{Materials and Methods}

\subsection{Experimental Fields}

Two Portuguese varieties of Triticum aestivum L. (Roxo and Paiva) obtained in the breeding Programme of the National Institute for Agriculture and Veterinary Research (INIAV), located in Elvas, Portugal, were cultivated in four experimental fields. Wheat fields 
were located at $37^{\circ} 57^{\prime} 09.68^{\prime \prime} \mathrm{N} ; 7^{\circ} 30^{\prime} 26.82^{\prime \prime} \mathrm{W}$ (field 1 ); $37^{\circ} 57^{\prime} 27.59^{\prime \prime} \mathrm{N} ; 8^{\circ} 08^{\prime} 05.50^{\prime \prime} \mathrm{W}$ (field 2); $37^{\circ} 58^{\prime} 56.10^{\prime \prime} \mathrm{N} ; 7^{\circ} 44^{\prime} 18.38^{\prime \prime} \mathrm{W}$ (field 3 ) and at $38^{\circ} 01^{\prime} 52.38^{\prime \prime} \mathrm{N} ; 7^{\circ} 52^{\prime} 53.72^{\prime \prime} \mathrm{W}$ (field 4).

Fields were sown at 30 December of 2018, with a rate of 350 seeds $/ \mathrm{m}^{2}$, and the harvest of fields 1 and 3 took place at 26 June of 2019, while for fields 2 and 4 this period finished on 12 July and 27 June of 2019, respectively. During plant cycles, the average maximum and minimum temperatures were $22{ }^{\circ} \mathrm{C}$ and $11{ }^{\circ} \mathrm{C}$, respectively (with maximum and minimum temperatures of $39{ }^{\circ} \mathrm{C}$ and $0{ }^{\circ} \mathrm{C}$, respectively). During this period, the maximum and minimum values of air humidity were $100 \%$ and $0 \%$, respectively (with maximum and minimum averages ranging between $69 \%$ and $11 \%$, respectively). The total rainfall accumulation was about $5.43 \mathrm{~mm}$ (with a daily maximum of $1.85 \mathrm{~mm}$ ).

Before sowing, fields were fertilized with $50 \mathrm{~kg} \mathrm{Zn/ha.} \mathrm{NPK} \mathrm{fertilization} \mathrm{was} \mathrm{ap-}$ plied before sowing (Foskamónio 12-24-22, $250 \mathrm{~kg} / \mathrm{ha}$, with 2.5\% N-nitric and 9.5\% Nammoniacal, $20-24 \%$ of phosphorus pentoxide soluble in citrate of neutral ammonium and water, $12 \%$ water soluble potassium oxide) and $\mathrm{N}$ was additionally applied in two top dressing (Nergetic DS 24/5-14, $200 \mathrm{~kg} /$ ha, with 24\% total nitrogen, 12\% nitrous nitrogen, $12 \%$ ammoniacal nitrogen, $5 \%$ water soluble $\mathrm{CaO}, 14 \%$ total $\mathrm{SO}_{3}$ and 0.03 water soluble $\mathrm{B}$ ). Fields were sown in a randomized block design with four repetitions, where fields 1, 2 and 3 presented 24 plots, with an area of $12 \mathrm{~m}^{2}(10 \mathrm{~m} \times 1.2 \mathrm{~m})$ each, comprising $0.4 \mathrm{~m}$ between plots and $3 \mathrm{~m}$ between repetitions. Field 4 comprised 72 plots (each 24 plots for a different zinc fertilizer application) with an area of $9.6 \mathrm{~m}^{2}(8 \mathrm{~m} \times 1.2 \mathrm{~m})$, with $0.4 \mathrm{~m}$ rows between plots and $2 \mathrm{~m}$ between repetitions. Each of the four experimental fields were divided into two sections and cultivated with both bread wheat varieties (Roxo and Paiva). During April and May, the agronomic biofortification comprised Zn foliar pulverization at booting, heading and grain milk stages (except on the plots sprayed with $\mathrm{ZnSO}_{4}$, as in this case foliar applications took place only at booting and heading). Each fertilizer was applied with three different concentrations. In field $1, \mathrm{ZnSO}_{4}$ was applied (two sprays-each with 0-control, 8,1 and $18.2 \mathrm{~kg} / \mathrm{ha}$; total applied-0 for the control and 16.20 and $36.40 \mathrm{~kg} / \mathrm{ha}$ ); field 2 was sprayed with Zinc-EDTA (three sprays, each with 0-control, 2.1 and $4.2 \mathrm{~kg} / \mathrm{ha}$; total applied -0 for the control and, 6.3 and $12.60 \mathrm{~kg} / \mathrm{ha}$ ); field 3 was pulverized with Tecnifol Zinc (three sprays, each with 0-control, 1.3 and 2.6; total applied-0 for the control, 3.9 and $7.8 \mathrm{~kg} / \mathrm{ha})$; field 4 was sprayed with all the three fertilizers $\left(\mathrm{ZnSO}_{4}\right.$, Zinc-EDTA and Tecnifol Zinc, with the concentrations mentioned above).

\subsection{Soil Analysis}

In fields 1, 2 and 3, soil samples (9) were collected from surface to a $30 \mathrm{~cm}$ deep, using a rectangular grid of $23 \times 22 \mathrm{~m}$. In field 4, soil samples were collected from surface to a $30 \mathrm{~cm}$ deep, using a rectangular grid of $38 \times 31 \mathrm{~m}$. Approximately $100 \mathrm{~g}$ of each sample was sieved, using a $2.0 \mathrm{~mm}$ mesh, to remove coarse materials, stones and other debris. Sample weight was recorded and, after drying for $24 \mathrm{~h}$ at $105{ }^{\circ} \mathrm{C}$, samples were taken to desiccation for $1 \mathrm{~h}$, followed by determination of dry mass and moisture. Thereafter, samples were placed in a muffle, heated for $4 \mathrm{~h}$, at $550{ }^{\circ} \mathrm{C}$ (until constant weight), and removed after cooling until $100^{\circ} \mathrm{C}$. Samples were then placed in a desiccator (for about $1 \mathrm{~h}$, until room temperature) and weighted to assess the percentage of organic matter.

Soil electrical conductivity and $\mathrm{pH}$ were determined using potentiometer, and after sample mixing (at a ratio of 1:2.5 $\mathrm{g}_{\text {soil }} \mathrm{mL}^{-1}$ water milli-q, for $1 \mathrm{~h}$ ), keeping thereafter the mixture at $25^{\circ} \mathrm{C}$, for $30 \mathrm{~min}$ in a thermal bath, followed by decantation of the supernatant [69].

Mineral content in soils were determined using an XRF analyzer (model XL3t $950 \mathrm{He}$ GOLDD +), under helium atmosphere [70].

\subsection{Zinc Contents and Deposition in Grain Tissues}

Zinc content in the whole wheat flour was determined using an XRF analyzer (model XL3t 950 He GOLDD +) under helium atmosphere [70]. For each sample, measurements were carried out in triplicate with emission of radiation for $180 \mathrm{~s}$. For data analysis, the software NITON Data Transfer (XL 3t-36653) was used. 
A micro-Energy Dispersive X-Ray Fluorescence system ( $\mu$-EDXRF) (M4 Tornado ${ }^{\mathrm{TM}}$, Bruker, Germany) was used to assess $\mathrm{Zn}$ deposition in grain tissues collected at harvest [65]. The X-ray generator was operated at $50 \mathrm{kV}$ and $100 \mu \mathrm{A}$ without the use of filters, to enhance the ionization of low- $Z$ elements. To a better quantification of the element, a set of filters between the X-ray tube and the sample, composed of three foils of $\mathrm{Al} / \mathrm{Ti} / \mathrm{Cu}$ (with a thickness of $100 / 50 / 25 \mu \mathrm{m}$, respectively) was used. All the measurements with filters were performed with a $600 \mu \mathrm{A}$ current. Detection of fluorescence radiation was performed by an energy-dispersive silicon drift detector, $X F \mathrm{Flash}^{\mathrm{TM}}$, with $30 \mathrm{~mm}^{2}$ sensitive area and energy resolution of $142 \mathrm{eV}$ for $\mathrm{Mn} \mathrm{K}_{\alpha}$. To better measure the distribution mapping of $\mathrm{Zn}$, grains were longitudinally cut in half, along the crease tissue, with a stainless-steel surgical blade. Measurements were carried out under 20 mbar vacuum conditions and performed directly on one side of the grains. These point spectra were acquired for $200 \mathrm{~s}$.

\subsection{Grain Yield, Test Weight, Thousand Kernel Weight, Moisture and Macroscopic Aspects}

After harvest, the grain was threshed and weighted. Grain yield was expressed as $\mathrm{kg}$ of dry matter per ha [12]. Additionally, test weight (expressed as $\mathrm{kg} / \mathrm{hL}$ ) was analyzed in a cytometer, and thousand kernel weight (TKW) was further determined.

Determination of grain moisture content was based on [71]. The Infratec ${ }^{\mathrm{TM}} 1241$ Grain Analyzer (Foss, Denmark) was used and $800 \mathrm{~g}$ of grain was added.

Macroscopic aspects were obtained using a 48 OIS $+8+5+2$ MP Quad Camera, coupled with a $32+8$ MP Dual Front Camera.

\subsection{Ash and Colorimetric Parameters of Whole Wheat Flour}

Ash content in wheat flour was determined according to [72]. Each sample (5 g), in triplicate, was weighted and incinerated for $2 \mathrm{~h}$, at $900{ }^{\circ} \mathrm{C}$, followed by desiccation until room temperature. Samples were therefore weighted, and the ash content was determined.

The colorimetric parameters (chromaticity parameters $\mathrm{a}^{*}$ and $\mathrm{b}^{*}$ and lightness, $\mathrm{L}^{*}$ ) of the whole wheat flour were analyzed (in triplicate) using a Minolta CR 400 colorimeter (Minolta Corp., Ramsey, NJ, USA), coupled to a sample vessel (CR-A504) [73]. The system of the Comission Internationale $d^{\prime}$ Éclaire (CIE) was applied using the illuminate $\mathrm{D}_{65}$. Parameter $\mathrm{a}^{*}$ indicated color variations between red $(+60)$ and green $(-60)$, while the parameter $\mathrm{b}^{*}$ color varied between yellow $(+60)$ and blue $(-60)$. The parameter $L^{*}$ represented the lightness of each sample, translating the variation of the tonality between dark (0) and light (100). The approximation of these coordinates to the null value translated neutral colors like white, grey and black.

\subsection{Statistical Analyses}

Data were statistically analyzed using software $R$ ( $R$ version 3.6.3). Statistical analysis included a principal component analysis and One-Way and Two-Way ANOVA $(p \leq 0.05)$ to assess significant differences. Based on the results, a Tukey's test for mean comparison was performed, considering a 95\% confidence level. Data normality and homogeneity of variance was also carried out.

\section{Conclusions}

Without foliar spraying, the edaphic characteristics of the wheat fields determined grain enrichment in Zn through this nutrient solubility and availability in the soil, which in turn is conditioned by interactions among a $\mathrm{pH}$ lower than 7 , organic matter (which can develop organic complexes with $\mathrm{Zn}$ ) and low electrochemical conductivity (that decreases water requirements). Additionally, $\mathrm{Zn}$ uptake by roots antagonistically interacted with other nutrients, namely $\mathrm{Ca}$ and S, and synergistically with Fe and Mn. Nevertheless, genotype characteristics of Roxo and Paiva further corroborated with the efficiency of root uptake kinetics. Moreover, for $\mathrm{Zn}$ biofortification, foliar pulverization with $\mathrm{ZnSO}_{4}$ became the best foliar fertilizer, whereas Zn-EDTA was the least effective. However, independent of the fertilizer applied, $\mathrm{Zn}$ accumulation prevailed in the embryo and vascular bundle 
and, to a lesser extent, in aleurone. Under the edaphic parameters and applied foliar fertilizers, in each wheat field and genotype, the grain yield and test weight in general were not negatively affected. Nonetheless, the different genotype characteristics of both wheat varieties triggered different yields when $\mathrm{ZnSO}_{4}$ (that gave the highest values in Paiva and Roxo) and Tecnifol Zinc were used. Screening Zn enrichment using, as referential, color parameters, could not be carried out, since a correlation between $\mathrm{Zn}$ enrichment in the grains and the color parameters $\mathrm{L}^{*}, \mathrm{a}^{*}$ or $\mathrm{b}^{*}$ did not occur. Moreover, lightness and redgreen transitions were found to be a conjunction of genotype characteristics, fertilization types and edaphic conditions prevailing in each field.

Author Contributions: Conceptualization, I.C.L. and F.C.L.; methodology, I.C.L., C.C.P., A.C.M. and A.R.F.C.; formal analysis, I.C.L., C.C.P., A.C.M., A.R.F.C., M.S., M.P., J.D., J.C.R., M.M.S., A.S.A., I.P.P., M.F.P., F.H.R., P.L., M.G., R.G.L. and P.S.C.; investigation, I.C.L., F.C.L., C.C.P., A.C.M. and A.R.F.C.; resources, M.P. and J.D.; writing-original draft preparation, I.C.L., F.C.L. and A.S.A.; writing-review and editing, I.C.L., F.C.L. and P.L.; supervision, F.C.L., M.P. and M.M.S.; project administration, F.C.L. All authors have read and agreed to the published version of the manuscript.

Funding: This research was funded by PDR2020, grant number 101-030835 and by the research center Grant N ${ }^{\circ}$. UID/FIS/04559/2020 to LIBPhys-UNL, from the FCT/MCTES/PIDDAC.

Institutional Review Board Statement: Not applicable.

Informed Consent Statement: Not applicable.

Data Availability Statement: Not applicable.

Acknowledgments: The authors thanks to the Sociedade Agrícola Saramago de Brito, Agro-Vale Longo, Lda, Francisco Palma, Instituto Politécnico de Beja and Associação de Agricultores do Baixo Alentejo for facilities in the wheat fields. We also thank to the research centers (GeoBioTec) UIDB/04035/2020 and (CEF) UIDB/00239/2020 for lab facilities.

Conflicts of Interest: The authors declare no conflict of interest.

\section{References}

1. United Nations, Department of Economics and Social Affairs, Population Division. World Population Prospects: The 2015 Revision, Key Findings and Advance Tables; Working Paper No. ESA/P/WP.241; United Nations, Department of Economics and Social Affairs, Population Division: New York, NY, USA, 2015.

2. Gaffney, J.; Challender, M.; Califf, K.; Harden, K. Building bridges between agribusiness innovation and smallholder farmers: A review. Glob. Food Sec. 2019, 20, 60-65. [CrossRef]

3. Zou, C.; Du, Y.; Rashid, A.; Ram, H.; Savasli, E.; Pieterse, P.J.; Ortiz-Monasterio, I.; Yazici, A.; Kaur, C.; Mahmood, K.; et al. Simultaneous biofortification of wheat with zinc, iodine, selenium, and iron through foliar treatment of a micronutrient cocktail in six countries. J. Agric. Food Chem. 2019, 67, 8096-8106. [CrossRef]

4. Ciccolini, V.; Pellegrino, E.; Coccina, A.; Fiaschi, A.I.; Cerretani, D.; Sgherri, C.; Quartacci, M.F.; Ercoli, L. Biofortification with iron and zinc improves nutritional and nutraceutical properties of common wheat flour and bread. J. Agric. Food Chem. 2017, 65, 5443-5452. [CrossRef]

5. Beaudreault, A.R. Nutrition Policy Primer: The Untapped Path to Global Health, Economic Growth, and Human Security; Center for Strategic \& International Studies: Washington, DC, USA, 2019. [CrossRef]

6. Cakmak, I.; Marzorati, M.; Van den Abbeele, P.; Hora, K.; Holwerda, H.T.; Yazici, M.A.; Savasli, E.; Neri, J.; Du Laing, G. Fate and bioaccessibility of iodine in food prepared from agronomically biofortified wheat and rice and impact of cofertilization with zinc and selenium. J. Agric. Food Chem. 2020, 68, 1525-1535. [CrossRef]

7. Cakmak, I.; Kutman, U.B. Agronomic biofortification of cereals with zinc: A review. Eur. J. Soil Sci. 2018, 69, 172-180. [CrossRef]

8. Mangueze, A.V.J.; Pessoa, M.F.G.; Silva, M.J.; Ndayiragije, A.; Magaia, H.E.; Cossa, V.S.I.; Reboredo, F.H.; Carvalho, M.L.; Santos, J.P.; Guerra, M.; et al. Simultaneous zinc and selenium biofortification in rice. Accumulation, localization and implications on the overall mineral content of the flour. J. Cereal Sci. 2018, 82, 34-41. [CrossRef]

9. Institute of Medicine. Dietary Reference Intakes for Vitamin A, Vitamin K, Arsenic, Boron, Chromium, Copper, Iodine, Iron, Manganese, Molybdenum, Nickel, Silicon, Vanadium, and Zinc; The National Academies Press: Washington, DC, USA, 2001. [CrossRef]

10. Wang, D.; Liu, K.; Cui, P.; Bao, Z.; Wang, T.; Lin, S.; Sun, N. Egg-White-Derived antioxidant peptide as an efficient nanocarrier for zinc delivery through the gastrointestinal system. J. Agric. Food Chem. 2020, 68, 2232-2239. [CrossRef]

11. Zaman, Q.; Aslam, Z.; Yaseen, M.; Ihsan, M.Z.; Khaliq, A.; Fahad, S.; Bashir, S.; Ramzani, P.M.A.; Naeem, M. Zinc biofortification in rice: Leveraging agriculture to moderate hidden hunger in developing countries. Arch. Agron. Soil Sci. 2018, 64, 147-161. [CrossRef] 
12. Gomez-Coronado, F.; Almeida, A.S.; Santamaria, O.; Cakmak, I.; Poblaciones, M.J. Potential of advanced breeding lines of bread-making wheat to accumulate grain minerals $(\mathrm{Ca}, \mathrm{Fe}, \mathrm{Mg}$ and $\mathrm{Zn})$ and low phytates under Mediterranean conditions. J. Agron. Crop Sci. 2019, 205, 341-352. [CrossRef]

13. Food and Agriculture Organization of the United Nations (FAO). World Food Situation-FAO Cereal Supply and Demand Brief. 2020. Available online: http://www.fao.org/worldfoodsituation/csdb/en/ (accessed on 24 May 2020).

14. FAO; WHO. Diet, Nutrition and the Prevention of Chronic Diseases. Report of a Joint FAO/WHO Expert Consultation; WHO Technical Report Series 916; World Health Organization: Geneva, Switzerland, 2003.

15. Cakmak, I. Biofortification of cereals with zinc and iron through fertilization strategy. In Proceedings of the 19th World Congress of Soil Science, Soil Solutions for a Changing World, Brisbane, Australia, 1-6 August 2010.

16. Begum, M.C.; Islam, M.; Sarkar, M.R.; Azad, M.A.S.; Huda, A.K.M.N.; Kabir, A.H. Auxin signaling is closely associated with Zn-efficiency in rice (Oryza sativa L.). J. Plant Interact. 2016, 11, 124-129. [CrossRef]

17. Chang, H.; Lin, C.; Huang, H. Zinc-induced cell death in rice (Oryza sativa L.) roots. Plant Growth Regul. 2005, 46, 261-266. [CrossRef]

18. Broadley, M.R.; White, P.J.; Hammond, J.P.; Zelko, I.; Lux, A. Zinc in plants. New Phytol. 2007, 173, 677-702. [CrossRef] [PubMed]

19. Rellán-Álvarez, R.; Giner-Martínez-Sierra, J.; Orduna, J.; Orera, I.; Rodríguez-Castrillón, J.A.; García-Alonso, J.I.; Abadía, J.; Álvarez-Fernández, A. Identification of a tri-iron(III), tri-citrate complex in the xylem sap of iron-deficient tomato resupplied with iron: New insights into plant iron long-distance transport. Plant Cell Physiol. 2010, 51, 91-102. [CrossRef] [PubMed]

20. Leitenmaier, B.; Küpper, H. Compartmentation and complexation of metals in hyperaccumulator plants. Front. Plant Sci. 2013, 4, 1-13. [CrossRef]

21. Garcia-Oliveira, A.L.; Chander, S.; Ortiz, R.; Menkir, A.; Gedil, M. Genetic basis and breeding perspectives of grain iron and zinc enrichment in cereals. Front. Plant Sci. 2018, 9, 1-13. [CrossRef]

22. Palmgren, M.G.; Clemens, S.; Williams, L.E.; Krämer, U.; Borg, S.; Schjørring, J.K.; Sanders, D. Zinc biofortification of cereals: Problems and solutions. Trends Plant Sci. 2008, 13, 464-473. [CrossRef]

23. Bouis, H.E.; Saltzman, A. Improving nutrition through biofortification: A review of evidence from HarvestPlus, 2003 through 2016. Glob. Food Sec. 2017, 12, 49-58. [CrossRef]

24. De Steur, H.; Mehta, S.; Gellynck, X.; Finkelstein, J.L. GM biofortified crops: Potential effects on targeting the micronutrient intake gap in human populations. Curr. Opin. Biotechnol. 2017, 44, 181-188. [CrossRef]

25. Gregory, P.J.; Wahbi, A.; Adu-Gyamfi, J.; Heiling, M.; Gruber, R.; Joy, E.J.M.; Broadley, M.R. Approaches to reduce zinc and iron deficits in food systems. Glob. Food Sec. 2017, 15, 1-10. [CrossRef]

26. Noulas, C.; Tziouvalekas, M.; Karyotis, T. Zinc in soils, water and food crops. J. Trace Elem. Med. Biol. 2018, 49, 252-260. [CrossRef]

27. Cakmak, I.; Pfeiffer, W.H.; McClafferty, B. Review: Biofortification of durum wheat with zinc and iron. Cereal Chem. 2010, 87, 10-20. [CrossRef]

28. Gomez-Coronado, F.; Poblaciones, M.J.; Almeida, A.S.; Cakmak, I. Zinc (Zn) concentration of bread wheat grown under Mediterranean conditions as affected by genotype and soil/foliar Zn application. Plant Soil 2016, 401, 331-346. [CrossRef]

29. Eichert, T.; Kurtz, A.; Steiner, U.; Goldbach, H.E. Size exclusion limits and lateral heterogeneity of the stomatal foliar uptake pathway for aqueous solutes and water-suspended nanoparticles. Physiol. Plant. 2008, 134, 151-160. [CrossRef] [PubMed]

30. Fernández, V.; Brown, P.H. From plant surface to plant metabolism: The uncertain fate of foliar-applied nutrients. Front. Plant Sci. 2013, 4, 1-5. [CrossRef] [PubMed]

31. Schreiber, L.; Schönherr, J. Determination of foliar uptake of chemicals: Influence of leaf surface microflora. Plant Cell Environ. 1993, 16, 743-748. [CrossRef]

32. Schönherr, J. Characterization of aqueous pores in plant cuticles and permeation of ionic solutes. J. Exp. Bot. 2006, 57, 2471-2491. [CrossRef] [PubMed]

33. Eichert, T.; Goldbach, H.E. Equivalent pore radii of hydrophilic foliar uptake routes in stomatous and astomatous leaf surfacesFurther evidence for a stomatal pathway. Physiol. Plant. 2008, 132, 491-502. [CrossRef] [PubMed]

34. Loneragan, J.F.; Snowgall, K.; Robson, A.D. Remobilization of nutrients and its significance in plant nutrition. In Transport and Transfer Process in Plants; Wardlaw, I.F., Passioura, J.B., Eds.; Academic Press: New York, NY, USA, 1976; pp. 463-469.

35. Marschner, H. Mineral Nutrition of Higher Plants; Academic Press: London, UK, 1995.

36. Zhang, Q.; Brown, P.H. Distribution and transport of foliar applied zinc in pistachio. J. Am. Soc. Hortic. Sci. 1999, 124, 433-436. [CrossRef]

37. Singh, B.; Kumar, S.; Natesan, A.; Singh, B.K.; Usha, K. Improving zinc efficiency of cereals under zinc deficiency. Curr. Sci. 2005, 88, 36-44.

38. Cerqueira, J.M.C. Solos e Clima em Portugal; Clássica Editora: Lisboa, Portugal, 2001.

39. Bhatt, R.; Hossain, A.; Sharma, P. Zinc biofortification as an innovative technology to alleviate the zinc deficiency in human health: A review. Open Agric. 2020, 5, 176-187. [CrossRef]

40. Dharejo, K.A.; Anuar, A.R.; Khanif, Y.M.; Samsuri, A.W.; Junejo, N. Spatial variability of Cu, Mn and Zn in marginal sandy beach ridges soil. Afr. J. Agric. Res. 2011, 6, 3493-3498. [CrossRef]

41. Manyevere, A.; Muchaonyerwa, P.; MnKeni, P.N.S.; Dhau, I. Spatial variability of selected soil micronutrients under smallholder crop production in Zanyokwe, Eastern Cape, South Africa. S. Afr. J. Plant Soil 2017, 34, 339-349. [CrossRef] 
42. Gao, X.; Hoffland, E.; Stomph, T.; Grant, C.A.; Zou, C.; Zhang, F. Improving zinc bioavailability in transition from flooded to aerobic rice: A review. Agron. Sustain. Dev. 2012, 32, 465-478. [CrossRef]

43. Ramzan, S.; Bhat, M.A.; Kirmani, N.A.; Rasool, R. Fractionation of zinc and their association with soil properties in soils of Kashmir Himalayas. Int. Inv. J. Agric. Soil Sci. 2014, 2, 132-142.

44. Dotaniya, M.L.; Meena, V.D. Rhizosphere effect on nutrient availability in soil and its uptake by plants: A review. Proc. Natl. Acad. Sci. India Sect. B Biol. Sci. 2015, 85, 1-12. [CrossRef]

45. Goulding, K.W.T. Soil acidification and the importance of liming agricultural soils with particular reference to the United Kingdom. Soil Use Manag. 2016, 32, 390-399. [CrossRef]

46. Ismail, A.M.; Heuer, S.; Thomson, M.J.; Wissuwa, M. Genetic and genomic approaches to develop rice germplasm for problem soils. Plant Mol. Biol. 2007, 65, 547-570. [CrossRef]

47. White, P.J.; Bowen, H.C.; Demidchik, V.; Nichols, C.; Davies, J.M. Genes for calcium-permeable channels in the plasma membrane of plant root cells. Biochim. Biophys. Acta Biomembr. 2002, 1564, 299-309. [CrossRef]

48. Pendias, A.K. Trace Elements in Soils and Plants, 4th ed.; CRC Press: Boca Raton, FL, USA, 2011. [CrossRef]

49. Shkolnik, M.J. Microelements in Plant Life; Izd. Nauka: Leningrad, Russia, 1974.

50. Kitagishi, K.; Yamane, H. Heavy Metal Pollution in Soils of Japan; Japan Science Society Press: Tokyo, Japan, $1981 ;$ p. 302.

51. Qaswar, M.; Hussain, S.; Rengel, Z. Zinc fertilization increases grain zinc and reduces grain lead and cadmium concentrations more in zinc-biofortified than standard wheat cultivar. Sci. Total Environ. 2017, 605-606, 454-460. [CrossRef]

52. Loneragan, J.F.; Webb, M.J. Interactions between zinc and other nutrients affecting the growth of plants. In Zinc in Soils and Plants: Developments in Plant and Soil Sciences; Robson, A.D., Ed.; Springer: Dordrecht, The Netherlands, 1993; Volume 55, pp. 119-134. [CrossRef]

53. Prasad, R.; Shivay, Y.S.; Kumar, D. Interactions of zinc with other nutrients in soils and plants-A review. Indian J. Fertil. 2016, 12, 16-26.

54. Zhao, F.J.; Su, Y.H.; Dunham, S.J.; Rakszegi, M.; Bedo, Z.; McGrath, S.P.; Shewry, P.R. Variation in mineral micronutrient concentrations in grain of wheat lines of diverse origin. J. Cereal Sci. 2009, 49, 290-295. [CrossRef]

55. Rengel, Z. Carbonic anhydrase activity in leaves of wheat genotypes differing in Zn efficiency. J. Plant Physiol. 1995, 147, 251-256. [CrossRef]

56. Ortiz-Monasterio, I.; Trethowan, R.; Holm, P.B.; Cakmak, I.; Borg, S.; Tauris, B.E.B.; Brinch-Pedersen, H. Breeding, transformation, and physiological strategies for the development of wheat with high zinc and iron grain concentration. In The World Wheat Book, $a$ History of Wheat Breeding; Bonjean, A.P., Angus, W.J., Van Ginkel, M., Eds.; Lavoisier: Copenhagen, Denmark, 2011 ; pp. 951-977.

57. Marles, R.J. Mineral nutrient composition of vegetables, fruits and grains: The context of reports of apparent historical declines. J. Food Compost Anal. 2017, 56, 93-103. [CrossRef]

58. Hacisalihoglu, G.; Kochian, L.V. How do some plants tolerate low levels of soil zinc? Mechanisms of zinc efficiency in crop plants. New Phytol. 2003, 159, 341-350. [CrossRef]

59. Krishna, T.P.A.; Ceasar, S.A.; Maharajan, T.; Ramakrishnan, M.; Duraipandiyan, V.; Al-Dhabi, N.A.; Ignacimuthu, S. Improving the zinc-use efficiency in plants: A review. SABRAO J. Breed. Genet. 2017, 49, 211-230.

60. Erenoglu, E.B.; Kutman, U.B.; Ceylan, Y.; Yildiz, B.; Cakmak, I. Improved nitrogen nutrition enhances root uptake, root-to-shoot translocation and remobilization of zinc $\left({ }^{65} \mathrm{Zn}\right)$ in wheat. New Phytol. 2011, 189, 438-448. [CrossRef]

61. Niyigaba, E.; Twizerimana, A.; Mugenzi, I.; Ngnadong, W.A.; Ye, Y.P.; Wu, B.M.; Hai, J.B. Winter wheat grain quality, zinc and iron concentration affected by a combined foliar spray of zinc and iron fertilizers. Agronomy 2019, 9, 250. [CrossRef]

62. Zhao, A.; Wang, B.; Tian, X.; Yang, X. Combined soil and foliar $\mathrm{ZnSO}_{4}$ application improves wheat grain $\mathrm{Zn}$ concentration and $\mathrm{Zn}$ fractions in a calcareous soil. Eur. J. Soil Sci. 2019, 1-14. [CrossRef]

63. Ozturk, L.; Yazici, M.A.; Yucel, C.; Torun, A.; Cekic, C.; Bagci, A.; Ozkan, H.; Braun, H.; Sayers, Z.; Cakmak, I. Concentration and localization of zinc during seed development and germination in wheat. Physiol. Plant. 2006, 128, 144-152. [CrossRef]

64. Ramos, I.; Pataco, I.M.; Mourinho, M.P.; Lidon, F.; Reboredo, F.; Pessoa, M.F.; Carvalho, M.L.; Santos, J.P.; Guerra, M. Elemental mapping of biofortified wheat grains using micro X-ray fluorescence. Spectrochim. Acta Part B At. Spectrosc. 2016, 120, 30-36. [CrossRef]

65. Cardoso, P.; Mateus, T.C.; Velu, G.; Singh, R.P.; Santos, J.P.; Carvalho, M.L.; Lourenço, V.M.; Lidon, F.; Reboredo, F.; Guerra, M. Localization and distribution of $\mathrm{Zn}$ and Fe in grains of biofortified bread wheat lines through micro- and triaxial-X-ray fluorescence spectrometry. Spectrochim. Acta Part B 2018, 141, 70-79. [CrossRef]

66. Alloway, B.J. Soil factors associated with zinc deficiency in crops and humans. Environ. Geochem. Health 2009, 31, 537-548. [CrossRef] [PubMed]

67. Ramzan, Y.; Hafeez, M.B.; Khan, S.; Nadeem, M.; Saleem-ur-Rahman; Batool, S.; Ahmad, J. Biofortification with zinc and iron improves the grain quality and yield of wheat crop. Int. J. Plant Prod. 2020, 14, 501-510. [CrossRef]

68. Ottman, M.J.; Doerge, T.A.; Martin, E.C. Durum grain quality as affected by nitrogen fertilization near anthesis and irrigation during grain fill. Agron. J. 2000, 92, 1035-1041. [CrossRef]

69. Pessoa, M.F.; Scotti-Campos, P.; Pais, I.; Feteiro, A.; Canuto, D.; Simões, M.; Pelica, J.; Pataco, I.; Ribeiro, V.; Reboredo, F.H.; et al. Nutritional profile of the Portuguese cabbage (Brassica oleracea L var. costata) and its relationship with the elemental soil analysis. Emir. J. Food Agric. 2016, 28, 381-388. [CrossRef] 
70. Pelica, J.; Barbosa, S.; Reboredo, F.; Lidon, F.; Pessoa, F.; Calvão, T. The paradigm of high concentration of metals of natural or anthropogenic origin in soils-The case of Neves-Corvo mine area (Southern Portugal). J. Geochem. Explor. 2018, 186, 12-23. [CrossRef]

71. EN 15948. Cereals—Determination of Moisture and Protein-Method Using Near-Infrared-Spectroscopy in Whole Kernels; European Committee for Standardization: Brussels, Belgium, 2015.

72. NP 519. Cereais e Derivados. Determinação do Teor de Cinza a $900^{\circ}$ C. Processo Corrente; Instituto Português de Qualidade: Caparica, Portugal, 1993; p. 5.

73. Ramalho, J.C.; Pais, I.P.; Leitão, A.E.; Guerra, M.; Reboredo, F.H.; Máguas, C.M.; Carvalho, M.L.; Scotti-Campos, P.; Ribeiro-Barros, A.I.; Lidon, F.J.C.; et al. Can elevated air $\left[\mathrm{CO}_{2}\right]$ conditions mitigate the predicted warming impact on the quality of coffee bean? Front. Plant Sci. 2018, 9, 1-14. [CrossRef] 